\title{
Hydrothermal processes related to some Triassic and Jurassic submarine basaltic complexes in northeastern Hungary, the Dinarides and Hellenides
}

\author{
Gabriella B. Kiss' ${ }^{1, *}$, Ferenc Molnár ${ }^{1,2}$ and Ladislav A. Palinkaš ${ }^{3}$ \\ ${ }^{1}$ Eötvös Loránd University, Faculty of Science, Department of Mineralogy, Pázmány P. stny 1/c, 1117 Budapest, Hungary \\ (*corresponding author: G. B. Kiss e-mail: gabriella.b.kiss@ttk.elte.hu, telephone number: +36-1-372-2500 ext. 8333) \\ 2present address: Geological Survey of Finland, PO. Box 96, FI-02151 Espoo, Finland \\ ${ }^{3}$ University of Zagreb, Faculty of Science, Institute of Mineralogy and Petrology, Horvatovac 95, 10000 Zagreb, Croatia \\ 39-64 17 Figs. 7 Tabs. \\ doi:10.4154/gc.2016.04
}

choss

Article history:

Received November 09, 2015

Revised and accepted January 04, 2016

Avaliable online February 29, 2016
Keywords: submarine basaltic volcanism, submarine hydrothermal processes, mineralogy and geochemistry of submarine fluid/ rock interaction, fluid inclusions, chlorite thermometry

\begin{abstract}
Comparative studies on hydrothermal alteration of submarine peperitic basalt occurrences related to the Triassic early rifting of the Neotethys were carried out in various parts of the Dinarides and Hellenides. The study areas included the displaced fragments of the Dinarides in the Darnó Unit, NE Hungary, the Kalnik Mts. in Croatia and the Vares-Šmreka area in Bosnia and Herzegovina. In the Hellenides, similar environments were studied in the Stragopetra Mts., Greece. Jurassic pillow basalts formed in a back-arc-basin of the Neotethys were also studied in the Szarvaskő Unit, NE Hungary, which also represents a displaced unit of Dinaridic origin. Within the submarine basaltic lava flows, six volcanic facies were distinguished. The hydrothermal alteration was characterised according to those facies. The first process was the albitisation of the rock-forming plagioclase at $\sim 300^{\circ} \mathrm{C}$ in all localities. During the higher temperature stage of the subsequent cooling, chloritisation in the ground mass is typical for all types of basalts, however chlorite and rarely quartz formed in the fractures and amygdales of the Triassic basalts, while chlorite, quartz and prehnite precipitated in the fractures of the Jurassic rocks. At lower temperatures of this cooling-related process, calcite is a common mineral filling up the larger amygdales, jig-saw type fractures and other open spaces, but some epidote, pumpellyite, prehnite and laumontite also occur in the Triassic basalts. The late stage alteration (occurring at the lowest temperature) is characterised by argillitisation at every locality. The observed hydrothermal alteration patterns also show slight differences according to the volcanic facies as a function of the distal/proximal setting in relation to the eruptive centres and the presence/absence of water-saturated and unconsolidated carbonate or siliciclastic sediments at the time of the emplacement of lava flows. The study revealed that the most important factors influencing mineralogy and zoning of hydrothermal alteration in these short lived local hydrothermal systems are the rapid cooling of the hydrothermal fluid, the dominance of the poorly evolved seawater as the source of hydrothermal fluid and the local, i.e. effective water/rock ratio, determined by the degree of fracturing in the rock. The mineralogical-textural peculiarities of the highly localised hydrothermal fluid/rock interaction in the studied submarine seamount type volcanoes are clearly different from the products of the large-scale hydrothermal processes occurring at mid-oceanic ridges. Recognition of these differences is important in the evaluation of ore potential in the Neotethyan realm or other areas with occurrences of submarine basaltic units.
\end{abstract}

\section{INTRODUCTION}

Correlation and comparison of the Triassic and Jurassic submarine basaltic units in the Darnó and Szarvaskő Units northeastern Hungary, and similar occurrences in the Dinarides and Hellenides have been in the focus of several studies during past decades (see e.g. BUDA \& KISS, 1980; BALLA et al., 1980; KUBOVICS 1984; BALLA, 1987; DOWNES et al., 1990; DOSZTÁLY \& JÓZSA, 1992; HARANGI et al., 1996; JÓZSA, 1999; HAAS \& KOVÁCS, 2001; SCHMID et al., 2008; ROBERTSON et al., 2009 and the references cited therein). The results of the most recent investigations suggest that the formation of the Triassic basaltic units found in NE Hungary and in the Dinarides and Hellenides can be related to the advanced stage of rifting of the Neotethys, while the Jurassic basalts occurring in the same mélange in NE Hungary have accumulated in a back-arc-basin or a marginal basin (HARANGI et al., 1996, AIGNER-TORRES \& KOLLER, 1999, KISS et al., 2008, 2010, 2012, KOVÁCS et al., 2008, 2010, HAAS et al., 2011). These basaltic units of different ages were emplaced into unconsolidated sediments (Triassic - lime-mud, Jurassic - fine grained siliciclastics) as discussed in detail in KISS et al. $(2010,2011,2012)$. 
Comparison of the characteristics of submarine hydrothermal activities which affected these basaltic suites provides an additional tool to the correlation among the Triassic localities. Comparison of their overall characteristics to the Jurassic system offers an opportunity to investigate the effect of the geotectonic setting on the peculiarities of submarine hydrothermal processes. This aids recognition of the time- and environmentindependent common characteristics of these hydrothermal systems. Submarine volcanism related hydrothermal systems at the oceanic ridges are quite well known and documented, especially because of the formation of economically important volcanogenic massive sulfide ore deposits (see e.g. FOUSTOUKOS \& SEYFRIED, 2007, PIRAJNO, 2009 and the references therein). As a contrary, submarine volcanism-related hydrothermal processes have scarcely been studied in other geodynamic settings, e.g. advanced stage of rifting. Distinguishing between the features of submarine hydrothermal alteration processes in the structurally-texturally similar basaltic rocks formed in different geotectonic settings is of obvious importance in mineral exploration. Here, we present the mineralogical-textural-geochemical characteristics and the temporal and spatial evolution of the fluid/rock interaction in these submarine basaltic rocks.

\section{REGIONAL SETTING}

\section{The Darnó Unit}

The Darnó Unit (Fig. 1.) is part of the Bükk Unit, located within the Pelso Unit of the ALCAPA block (ALpine, CArpathian, PAnnonian, CSONTOS, 1995, SCHMID et al. (2008). It comprises an area of ca. $7 \mathrm{~km}^{2}$ in NE Hungary (centred on $\sim \mathrm{N} 47.936810$, E 20.163246), in the vicinity of the city of Eger. According to the latest tectonic models, the Darnó Unit forms the uppermost nappe in the complex structure of the Bükk Unit (which consists of four stacked nappes) (CSONTOS, 1995, CSONTOS, 1999, HAAS \& KOVÁCS, 2001, KOVÁCS et al., 2008).

The Darnó Unit consists of predominantly Triassic and subordinately Jurassic submarine basaltic suites and associated Triassic and Jurassic sedimentary rocks. The magmatic suites are pillow basalt sequences, however, in the Triassic rocks, limey peperitic facies (i.e. unconsolidated sediment-lava mixing at the time of rock formation, SKILLING et al., 2002) also commonly occur (KISS et al., 2008, 2010, 2012, KOVÁCS et al., 2010). Recent geochemical and volcanological studies of these Triassic magmatic rocks suggest their emplacement occurred in an advanced rift-related tectonic setting. The whole
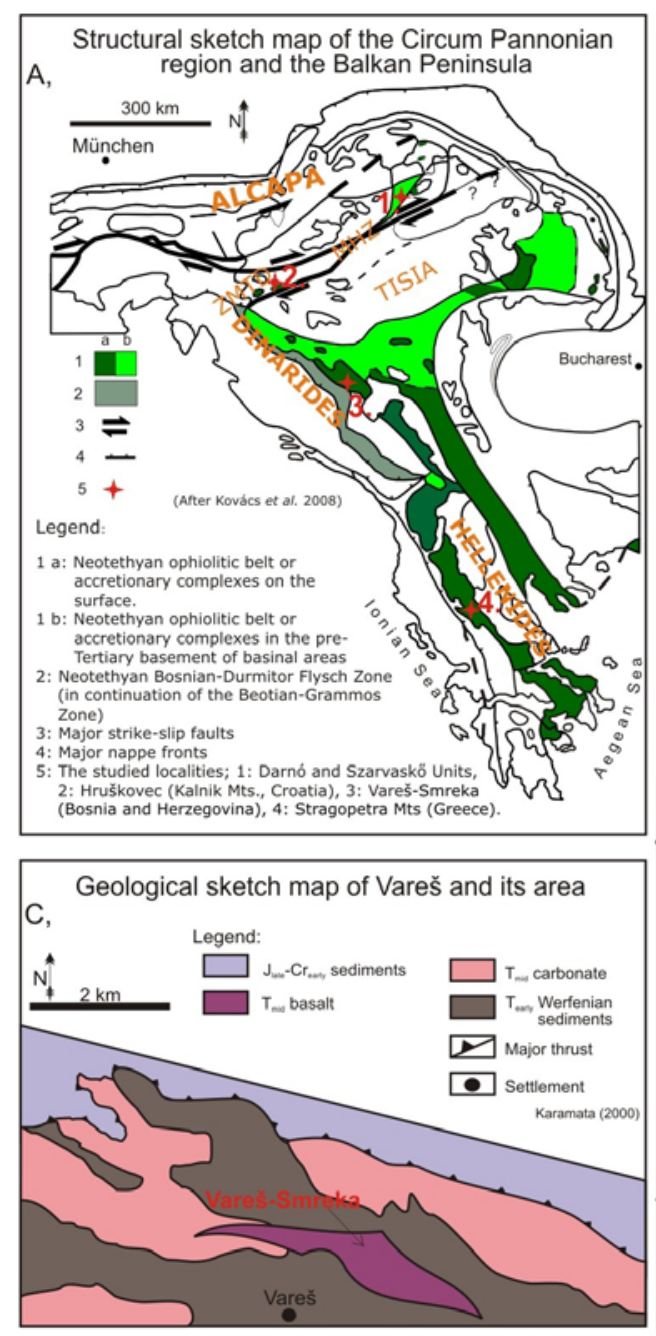
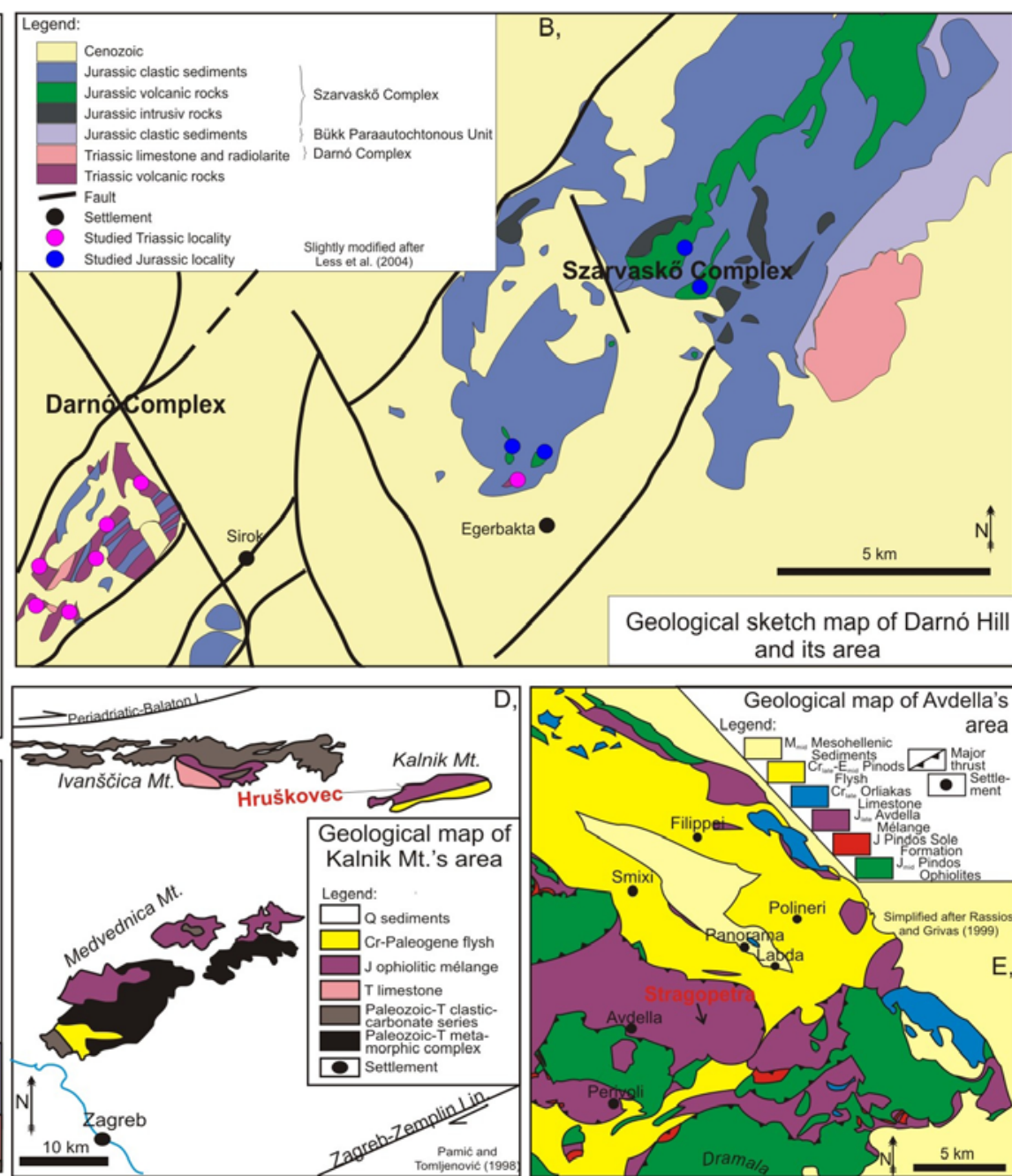

Figure 1. Geological maps of the studied areas. A, Structural sketch map of the Circum-Pannonian Region and the Balkan Peninsula. B, Geological sketch map of the Darnó and Szarvaskő Units. C, Geological sketch map of the area of Vareš. D, Geological sketch map of the area of Hruškovec. E, Geological sketch map of the Avdella Mélange. The studied localities are marked on each map. 
unit is interpreted as an accretionary mélange complex (BALLA et al., 1980, BUDA \& KISS, 1980, DIMITRIJEVIĆ et al., 2003, KOVÁCS et al., 2008, 2010, KISS et al., 2008, 2010, 2012). Signs of Alpine low grade metamorphism were observed nearby in the Bükk Mts. (see ÁRKAI, 2001 and references therein) and its effects on the Darnó Unit were documented by MOLNÁR et al. (2015).

\section{The Szarvaskő Unit}

The Szarvaskő Unit (Fig. 1.) is also part of the Bükk Unit, within the ALCAPA block. It forms a nappe below the uppermost Darnó Unit, with outcrops mostly confined to a synform structure in the vicinity of the village of Szarvaskö (N 47.988742, E 20.332144) (CSONTOS, 1995, DOSZTÁLY et al., 1998).

The Szarvaskö Unit consists of an incomplete Jurassic ophiolitic sequence intercalated with some deep water siliciclastic sediments. Besides the well developed pillow basalt series with local siliciclastic peperite (KISS et al., 2011), gabbro and related plagiogranite, wehrlite, piroxenite and hornblendite also occur. However, other ultramafic rocks of true ophiolitic sequences are missing (SZENTPÉTERY, 1953, BALLA, 1984, DOSZTÁLY et al., 1998, PELIKÁN ed. 2005). The $\mathrm{K}$-Ar age of the magmatic rocks is $165+/-5 \mathrm{Ma}$ and $166+/-8$ Ma according to ÁRVÁNÉ SÓS et al. (1987). BALOGH \& PÉCSKAY (2001) obtained an Ar-Ar plateau age of $162.9+/-$ $0.9 \mathrm{Ma}$ for contact-metasomatic K-mica occurring along the intrusive contact of a gabbro intrusion and host sediments. KOHÚT \& KISS (2013) reported $170+/-9$ Ma based on chemical EMP dating of monazite of the plagiogranite associated with the gabbroic intrusion. Current views suggest that formation of the incomplete ophiolitic sequence at Szarvaskö is related to the opening of a back-arc-basin or a marginal basin (AIGNER-TORRES \& KOLLER, 1999, CSONTOS, 2000, HAAS et al., 2011). Its differentiation from characteristic midoceanic ridge related rocks was also proven by KISS et al. (2011). ÁRKAI (1983), ÁRKAI et al. (1995), SADEK GHABRIAL et al. (1996), ÁRKAI (2001), PÉNTEK et al. (2006) and KISS et al. (2012) have also shown the occurrence of a very low and low grade Alpine regional metamorphism related alteration mineral assemblage of Cretaceous age.

\section{Localities in the Dinarides}

The Kalnik Mts. (Fig. 1.) comprise two main tectonostratigraphic units in the northern part of Croatia (centred on $\sim \mathrm{N}$ 46.150374, E 16.442340), in the Zagorje-Mid-Transdanubian Zone (ZMTZ) of the NW Dinarides. One unit is the strongly tectonised ophiolitic mélange, the other being the late Cretaceous-Palaeogene flysch. The mélange mostly exhibits features characteristic of the Dinarides, and is therefore interpreted as the most northwestern occurrence of the Dinaridic Ophiolite Zone (PAMIĆ \& TOMLJENOVIĆ, 1998).

The area of Vareš (N 44.161424, E 18.326386) (Fig. 1.) is located in Bosnia and Herzegovina, in the Central Dinarides. According to TRUBELJA et al. (2004) the Borovica-VarešČeljanovići-Kalinovik Zone is part of the Palaeozoic-Mesozoic allochthonous series. Recently, HRVATOVIĆ (2006) interpreted this zone as a part of the Dinaride ophiolitic mélange.
Triassic pillow basalt series and the limey peperitic facies rocks are important constituents of both ophiolitic mélange occurrences. In the Kalnik Mts., recent studies suggested a Neotethyan rifting related origin for the pillow basalts (PALINKAS et al., 2000, 2008, KISS et al. 2012). At Vareš, controversy surrounds interpretations of the origins of the rock. TRUBELJA et al. (2004) concluded subduction related formation, while PAMIĆ (1984), KARAMATA et al. (2000) and KISS et al. (2012) presented observations strongly supporting a riftrelated origin of the basaltic volcanism.

\section{Localities in the Hellenides}

The Avdella Mélange Formation (Fig. 1.) of Jurassic age occurs in NW Greece, within the Pindos Zone of the Hellenides. The mélange with basaltic and other magmatic and sedimentary blocks is one of the five main tectonostratigraphic units of the Pindos Zone. The accretionary mélange forms a nappe below the Pindos Ophiolites (JONES \& ROBERTSON, 1991, RASSIOS \& MOORES, 2006) occurring in the vicinity of the village of Avdella (N 40.007489, E 21.125159) in the Stragopetra Mts.

Based on the geochemistry of the pillow basalt blocks, JONES \& ROBERTSON (1991) argued that their formation took place in a mid-oceanic ridge environment, while KOVÁCS et al. (2010), KISS et al. (2012) and OZSVÁRT et al. (2012) suggested a Neotethyan rifting related origin and Triassic age (from fossil evidence in the limestones of the peperitic facies).

\section{Correlation possibilities}

The current geodynamic models correlate the Darnó Unit with the Triassic submarine basalt occurrences in the northwestern parts of the Dinarides (DIMITRIJEVIĆ et al., 2003, HAAS \& KOVÁCS, 2001, KOVÁCS et al., 2010, HAAS et al. 2011, KISS et al., 2008, 2010, 2012). Geological correlation summarised in DIMITRIJEVIĆ et al. (2003) and HAAS et al. (2011) also support the Dinaridic origin of the submarine magmatic and sedimentary rocks of the Szarvaskő Unit. However, results of KOVÁCS et al. (2010) and KISS et al. (2012) have also extended this correlation to localities in the Hellenides.

Thus, the studied NE Hungarian, Dinaridic and Hellenidic units represent remnants of the Neotethyan accretionary complexes (DIMITRIJEVIĆ et al., 2003, HAAS et al., 2011). The NE Hungarian ones were transported from the northwestern Dinarides to the current position along the Mid-Hungarian Lineament by approx. $400 \mathrm{~km}$ of horizontal displacement during the Alp-Carpathian collisional processes (CSONTOS \& VÖRÖS, 2004, SCHMID et al., 2008).

\section{STUDY METHODS}

Field studies were carried out in quarries and at outcrops of the Darnó Unit and Szarvaskő Unit (NE Hungary), Kalnik Mts. (N Croatia), Vareš area (Central Bosnia-Herzegovina) and in the Stragopetra Mts. (N Greece). Field recognition of volcanic facies and representative sampling of relatively fresh and hydrothermally altered rocks were the focus of field studies. 
Thin-section petrographic study of samples with emphasis on observation of the distinctive textures of rocks and hydrothermal alteration mineral assemblages was undertaken. An AMRAY 1830 SEM-EDS instrument with PV9800 type detector at the Department of Petrology and Geochemistry of the Eötvös Loránd University was also used for the petrographic characterisation of mineral assemblages. EDS analyses were completed with focused electron beam with $20 \mathrm{kV}$ accelerating potential, $1 \mathrm{nA}$ beam current and 100s detection time. The instrument was calibrated using well known natural and synthetic standards. The average detection limits were $0.1 \mathrm{wt} \%$ for the analysed elements.

X-Ray Powder Diffraction (XRPD, at the Department of Mineralogy of the Eötvös Loránd University) aided determination of other mineral phases. A Siemens D-5000 type diffractometer with Bragg-Brentano geometric emission $(\Theta-\Theta$ working method, $\mathrm{Cu} \mathrm{K} \alpha(\lambda=0.154178 \mathrm{~nm})$, secondary graphite crystal monochromator and scintillation detector was used together with the EVA software (Bruker-AXS Diffrac Plus) for data analysis.

Chlorite compositions from different textural settings facilitated temperature determination of fluid/rock interaction via wavelength dispersive (WDS) electron microprobe analyses (EPMA). Calibrations by KRANIDIOTIS \& MACLEAN (1987), CHATELINEAU \& IZQUIERDO (1988) and ZANG \& FYFE (1995) aided determination of chorite formation temperatures, depending on the measured $\mathrm{Al}(\mathrm{IV})$ and $\mathrm{XFe}$ values of the individual crystals. These methods bear about $20^{\circ} \mathrm{C}$ uncertainty of formation temperature estimation. The EPMA analyses of chlorite were performed at the Carleton University (Ottawa, Canada) and at the Masaryk University (Brno, Czech Republic). Elemental distribution maps of selected basalt samples were prepared at the Eugen Stumpfl Laboratory of the University Centre of Applied Geoscience, University of Leoben, Austria. At the Carleton University, the quantitative analyses of chlorite were completed using $15 \mathrm{kv}$ accelerating voltage and a beam current of $20 \mathrm{nA}$. The detection limits were as follows: $\mathrm{SiO}_{2}, \mathrm{TiO}_{2}, \mathrm{Cr}_{2} \mathrm{O}_{3}, \mathrm{MgO}$ and $\mathrm{Cl}-0.03 \mathrm{wt} \% ; \mathrm{Al}_{2} \mathrm{O}_{3}$, $\mathrm{K}_{2} \mathrm{O}, \mathrm{CaO}$ and $\mathrm{Na}_{2} \mathrm{O}-0.02 \mathrm{wt} \%$; $\mathrm{MnO}, \mathrm{NiO}$ and $\mathrm{F}-0.04 \mathrm{wt} \%$; $\mathrm{FeO}-0.05 \mathrm{wt} \%$. At the University of Leoben, elemental mapping was performed in WDS mode, with $15 \mathrm{kV}$ accelerating voltage and $10 \mathrm{nA}$ beam current. At the Masaryk University, CAMECA SX 100 type instrument with $15 \mathrm{kV}$ accelerating potential and a beam current of $10 \mathrm{nA}$ was used for determination of the major element compositions of chlorite. The detection limits were as follows: $0.06 \mathrm{wt} \%$ for $\mathrm{Na}, 0.04 \mathrm{wt} \%$ for $\mathrm{Si}$ and $\mathrm{V}, 0.035 \mathrm{wt} \%$ for $\mathrm{Al}, 0.045 \mathrm{wt} \%$ for $\mathrm{Mg}$ and $\mathrm{K}, 0.03 \mathrm{wt} \%$ for $\mathrm{Ca}, \mathrm{Cr}, \mathrm{Cl}$ and $\mathrm{Ti}, 0.12 \mathrm{wt} \%$ for $\mathrm{Ba}, 0.08 \mathrm{wt} \%$ for $\mathrm{Fe}$ and $\mathrm{Ni}$, $0.07 \mathrm{wt} \%$ for $\mathrm{Mn}$ and $\mathrm{F}$ and $0.2 \mathrm{wt} \%$ for $\mathrm{Zn}$. A suite of reliable natural and synthetic minerals and compounds were used as calibration standards at all laboratories.

Fluid inclusion petrography and microthermometry were carried out at the Department of Mineralogy, Eötvös Loránd University, on 80-100 $\mu \mathrm{m}$ thick, double polished sections of hydrothermal calcite from various volcanic and hydrothermal facies of basalt. Equipment was a Chaixmeca-type and Linkam FT-IR 600 type heating-freezing stage mounted on an Olympus BX-51 type polarizing microscope with $1000 \mathrm{x}$ opical magnification capability. Precision of the microthermometric measurements was $\pm 0.1{ }^{\circ} \mathrm{C}$ below $0{ }^{\circ} \mathrm{C}$, and $\pm 1{ }^{\circ} \mathrm{C}$ above it. $\mathrm{CO}_{2}$ and $\mathrm{H}_{2} \mathrm{O}$ synthetic fluid inclusions were used for all equipment calibration. Interpretation of microthermometric data involved using a macro program in MS Excel, developed in Visual Basic environment by the first author, using the methods of HALL et al. (1988), NADEN (1996), POTTER \& CLYNNE (1978) and ZHANG \& FRANTZ (1987).

Geochemical analysis of rock samples were carried out at the laboratory of the ALS Laboratory Group (Vancouver, Canada) and in the geochemical laboratory of the Hungarian Geological Institute. Geochemical data (8 samples) were published in KISS et al. (2012) and 19 samples were analysed in this study. The ALS Laboratory used ICP-AES to determine the major elements, Pt, Pd and Au, and ICP-MS to analyse the trace elements. Detection limits and analytical procedures are described in the official booklet of ALS ${ }^{1}$. The Hungarian Geological Institute analysed the major elements with ICP-AES, the trace elements with ICP-MS or ICP-AES, and Hg content with AAS. Detection limits and analytical procedures are described in the accreditation documentation of the laboratory ${ }^{2}$. Major and trace element data were interpreted using the Petrograph software (PETRELLI et al., 2005). Mass transfer calculations (MTC) were also performed, according to the method described in GRANT (1986), MACLEAN \& KRANIDIOTIS (1987), BRAUHART et al. (2001) and ULRICH \& HEINRICH (2002).

\section{RESULTS}

Field study

Six different volcanic facies can be distinguished in submarine lava flows: (1) coherent basalt, (2) closely packed pillow basalt, (3) peperitic pillow basalt, (4) in situ hyaloclastite breccia, (5) pillow fragmented hyaloclastite breccia and (6) isolated pillow breccia facies (PALINKAŠ et al., 2008, see also Fig. 16. below).

The quarry at Hruškovec exposes all six distinguishable volcanic facies of a submarine lava flow (PALINKAŠ et al., 2008, KISS et al., 2008). It was therefore used as the basis of comparison for volcanological features in other similar submarine basaltic volcanic centres. Its characteristic features are summarised in the above referenced citations, and not repeated here. The closely packed pillow, peperitic pillow, in situ hyaloclastite and the pillow fragmented hyaloclastite breccia facies were all detected in five studied quarries and several outcrops in the Darnó Unit. The studied quarry and the surveyed smaller natural and artificial outcrops in the Szarvaskö Unit expose three main volcanic facies: closely packed pillow, peperitic pillow and pillow fragmented hyaloclastite breccia facies. The quarry and several small outcrops in the Vareš-Smreka area expose the closely packed pillow facies and the peperitic pillow facies. Three large artificial outcrops (a quarry and two roadcuts) and two smaller natural outcrops were studied in detail on the western, southern and southeastern slopes of the Stragopetra Mts. These exposures contain closely packed pil-

1available at: http://www.alsglobal.com/Our-Services/Minerals/Geochemistry/Downloads

${ }^{2}$ accreditation number: NAT-1-1302/2012 

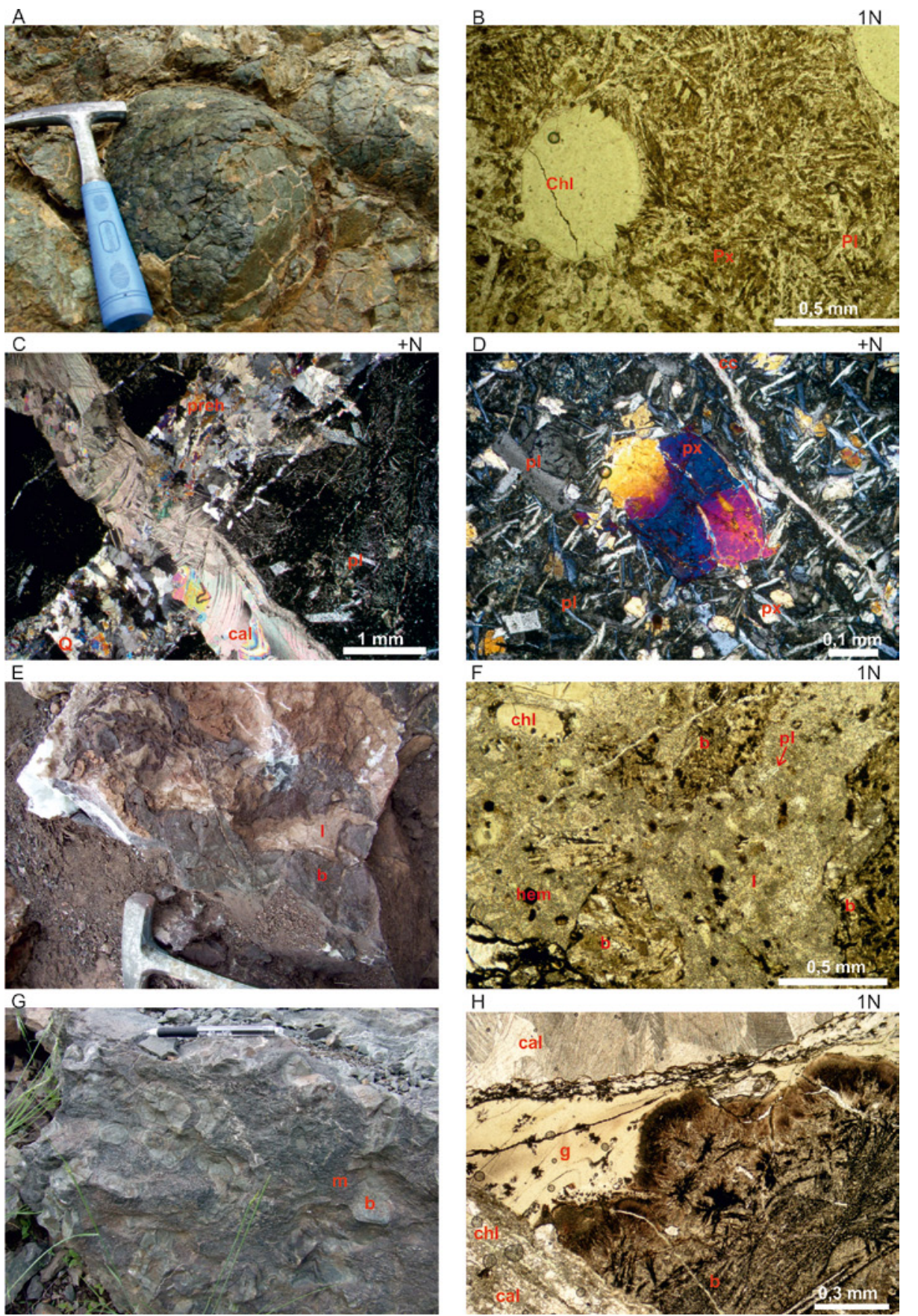

Figure 2. Macroscopic and microscopic photos of the observed facies. A, Closely packed pillow with abundant, mostly calcite-filled jig-saw veins and a small amount of interpillow hyaloclastite breccia (Nagy-Rézoldal Quarry, Darnó Unit, Hungary). B, Intersertal textured Triassic basalt with small, chlorite filled amygdales (Nagy-Rézoldal Quarry, Darnó Unit, Hungary). C, Older, higher temperature quartz and prehnite filled cooling crack is cut by a younger, lower temperature calcite vein in a Triassic basalt (RM-131 drillcore, Darnó Unit, Hungary). D, Porphyryc textured Jurassic basalt with coarse grained pyroxene showing compositional zonation. The rock is cut by a thin, cooling related calcite vein (Egerbakta Quarry, Szarvaskő Unit, Hungary). E, Chaotic mingling of basalt and pinkish limestone from a Triassic peperitic facies (Stragopetra, Greece). F, Chaotic mingling of basalt and limestone from a Triassic peperitic facies. The limestone contains basalt clasts, chloritised glassy shards as well as pieces of plagioclase laths (Bájpatak Quarry, Darnó Unit, Hungary). G, Pillow fragmented hyaloclastite breccia at a Jurassic basalt location (Egerbakta Quarry, Szarvaskő Unit, Hungary). H, Glassy basaltic clast in a Triassic hyaloclastite breccia. Textural variation from the glassy, through sphaerolitic till variolitic is observable, while the cementing hydrothermal material is mostly calcite (RM-131 drillcore, Darnó Unit, Hungary). Abbreviations: b: basalt, cal: calcite, chl: chlorite, g: glass, hem: haematite, l: limestone, m: matrix, pl: plagioclase, px: pyroxene, Q: quartz, preh: prehnite. low facies, but the most abundant is the peperitic pillow facies.

Petrography

Detailed petrographic investigations, coupled with XRPD and SEM-EDS analyses as well as EPMA elemental mapping revealed mineralogical, petrographic and textural similarities and differences between the studied localities. Results are summarised in Table 1. and presented below, highlighting the common and different features recognised in the four volcanic facies occurring in the study area.

\section{The closely packed pillow facies}

The closely packed pillow facies, formed around the coherent pillows of the lava flow, as a moderately distal facies in relation to the eruption centre (PALINKA ̌ et al., 2008). They are composed of grey, greyish green, or reddish grey basaltic pillows $30-100 \mathrm{~cm}$ in diameter at every locality (Fig. 2A). The texture of the basalt is sphaerolitic, variolitic or interstertal. At the Triassic localities, the rock is composed mostly of altered plagioclase laths and $40-50 \%$ microcrystalline and glassy groundmass, while the occurrence of clinopyroxene laths is very rare (Fig. 2B,C). Porphyry texture occurs only rarely, when the weakly altered (argillitised) plagioclase occur in two size groups: $>1 \mathrm{~mm}$ and $0.1-0.4 \mathrm{~mm}$. The SEM-EDS studies proved that the plagioclase is predominantly albite in composition (Table 2, Fig. 3A). Elemental mapping by EPMA revealed that these crystals contain more $\mathrm{Na}$ and less $\mathrm{Ca}$ closer to the margins of the pillows (where sphaerolitic-variolitic texture dominates), than in their inner parts (where variolitic-intersertal texture dominates) (Fig. 4A-I). The augitic pyroxene in the Triassic basalts is rather homogeneous (MORIMOTO, 1989; Table 3, Fig. 3B). Calcite, chlorite and opaque mineral pseudomorphs after the 0.5-0.8 mm large olivine phenocrysts are common in the Triassic basalts. The groundmass is altered to chlorite, clay minerals, calcite, haematite and titanite. The XRPD analyses revealed the presence of chlorite-smectite, chlorite-illite interlayering, celadonite and smectite. Disseminated pyrite, 
Table 1. Petrographical characteristics of the Triassic and Jurassic rocks.

\begin{tabular}{|c|c|c|c|c|}
\hline & & & Triassic & Jurassic \\
\hline \multirow{7}{*}{ 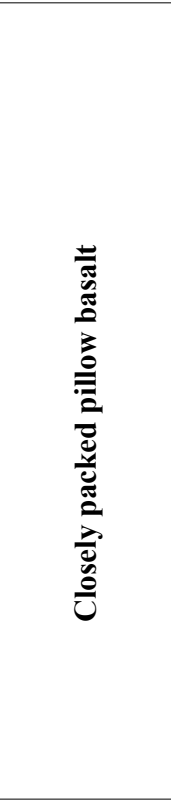 } & \multirow[t]{3}{*}{ Rock } & Texture & $\begin{array}{l}\text { sphaerolitic, variolitic, rarely } \\
\text { intersertal }\end{array}$ & porphyric intersertal \\
\hline & & Main minerals & $\begin{array}{l}\text { plagioclase, rare clinopyro- } \\
\text { xene (augite) }\end{array}$ & $\begin{array}{l}\text { plagioclase, clinopyroxene } \\
\text { (augite) }\end{array}$ \\
\hline & & Other components & $\begin{array}{l}\text { pseudomorphs after olivine, } \\
\text { pyrite, chalcopyrite, hematite, } \\
\text { bornite, titanite }\end{array}$ & pyrite, chalcopyrite \\
\hline & \multirow[t]{4}{*}{ Alteration } & Groundmass & \multicolumn{2}{|c|}{$\begin{array}{l}\text { chlorite, chlorite-smectite and chlorite-illite interlayering, } \\
\text { celadonite, smectite, calcite }\end{array}$} \\
\hline & & Plagioclase & $\begin{array}{l}\text { albite, partly atered to clay } \\
\text { minerals }\end{array}$ & albite \\
\hline & & Hydrothermal infillings & $\begin{array}{l}\text { amygdales, jig-saw veins, } \\
\text { thin veinlets, former feeding } \\
\text { channels, mineral bands of } \\
\text { pyjamas-type pillows, inter- } \\
\text { pillow hyaloclastite }\end{array}$ & $\begin{array}{l}\text { thin veinlets, interpillow } \\
\text { hyaloclastite }\end{array}$ \\
\hline & & Hydrothermal minerals & $\begin{array}{l}\text { chlorite, quartz, calcite, lau- } \\
\text { montite, haematite, epidote, } \\
\text { prehnite }\end{array}$ & $\begin{array}{l}\text { chlorite, quartz, calcite, epi- } \\
\text { dote, prehnite }\end{array}$ \\
\hline \multirow{7}{*}{ } & \multirow[t]{4}{*}{ Rock } & Basalt & $\begin{array}{l}\text { similar, than in the closely } \\
\text { packed pillow }\end{array}$ & $\begin{array}{l}\text { similar, than in the closely } \\
\text { packed pillow }\end{array}$ \\
\hline & & Sedimentary rock & red micritic limestone & black aleurolite \\
\hline & & Sedimentary rock composition & $\begin{array}{l}\text { calcite, bioclasts, plagioclase, } \\
\text { glassy shards, pyroxene }\end{array}$ & $\begin{array}{l}\text { quartz, chalcedony, albite } \\
\text { (alteration products) }\end{array}$ \\
\hline & & Amount of sedimentary rock & $50-70 \%$ & $20-30 \%$ \\
\hline & \multirow[t]{3}{*}{ Alteration } & Groundmass & haematite & quartz, chalcedony, albite \\
\hline & & Hydrothermal infillings & $\begin{array}{l}\text { thin veinlets, jigsaw veins, } \\
\text { amygdales }\end{array}$ & thin veinlets \\
\hline & & Hydrothermal minerals & $\begin{array}{l}\text { calcite, chlorite, haematite, } \\
\text { prehnite, laumontite }\end{array}$ & $\begin{array}{l}\text { calcite, quartz, chlorite, preh- } \\
\text { nite, albite }\end{array}$ \\
\hline \multirow{3}{*}{ 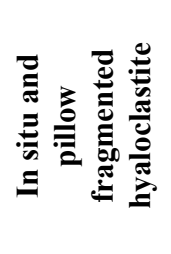 } & \multirow[t]{2}{*}{ Rock } & Breccia clasts & $\begin{array}{l}\text { pillow basalt, fractured } \\
\text { basalt, glass shards, micritic } \\
\text { limestone }\end{array}$ & fractured basalt, glass shards \\
\hline & & Breccia matrix & $\begin{array}{l}\text { quartz, chlorite, calcite, preh- } \\
\text { nite, pumpellyite }\end{array}$ & $\begin{array}{l}\text { quartz, chlorite, prehnite and } \\
\text { pumpellyite }\end{array}$ \\
\hline & Alteration & Basalt clasts & haematite, chlorite & chlorite \\
\hline
\end{tabular}

chalcopyrite, haematite (also pseudomorphs after pyrite) and bornite also occur in the basalt.

Fluid/rock ineteraction processes and percolation of upheated sea-water in the piles of Triassic basaltic lava flows, resulted in precipitation of hydrothermal minerals filling the amygdales (0.1-5 $\mathrm{mm}$ in size), cooling of related jig-saw veins of 1-3 mm thickness, infilling of the $0.1-0.5 \mathrm{~mm}$ thin cross-cutting veins and former internal feeding channels of the lava. The interpillow hyaloclastite breccia is also cemented by hydrothermal minerals (Fig. 2A, B, C). The thin veinlets and the smaller (0.1-1 mm) amygdales contain only the oldest mineral paragenesis, while the bigger $(1-5 \mathrm{~mm})$ amygdales, the mineral bands in the pyjama-type pillows, the former feeding channels, and the jig-saw type veins also contain the older hydrothermal mineral phases along their walls, with younger mineral infillings of different composition in their central parts. The small amygdales are generally infilled with chlorite (Fig. 2B), but sometimes quartz also occurs. Larger amygdales are most- ly infilled with calcite and lesser amounts of chlorite and quartz. The thin veinlets contain chlorite, quartz, epidote, calcite and prehnite, whereas the jig-saw type veins are mostly infilled with a calcite-quartz-chlorite assemblage (Fig. 2C). The mineral bands of the pyjama-type pillows contain mostly calcite with a small amount of haematite, quartz, chlorite and laumontite. Infillings of the former feeding channels are mostly calcite. The $0.5-5 \mathrm{~cm}$ glassy shards of the interpillow hyaloclastite breccia are cemented with a mixture of chlorite, calcite, quartz, epidote and prehnite at all the studied localities.

Alteration features in the Jurassic basalt slightly differ from the peculiarities of the Triassic basalt described above. It is generally characterised with a porphyric-intersertal texture and contains more clinopyroxene and lesser amounts of microcrystalline and glassy groundmass (Fig. 2D). The weakly altered (argillitised) plagioclase and fresh pyroxene phenocrysts occur in two size groups: $>1 \mathrm{~mm}$ and $0.1-0.4 \mathrm{~mm}$. The SEMEDS studies proved that the plagioclase is predominantly 
Table 2. Results of the SEM-EDS studies (plagioclase analyses).

\begin{tabular}{|c|c|c|c|c|c|c|c|c|c|c|c|c|c|c|}
\hline & & & $\mathrm{Na}_{2} \mathrm{O}$ & $\mathrm{Al}_{2} \mathrm{O}_{3}$ & $\mathrm{SiO}_{2}$ & $\mathrm{~K}_{2} \mathrm{O}$ & $\mathrm{CaO}$ & Total & $\mathrm{Na}$ & Al & $\mathbf{S i}$ & $\mathbf{K}$ & $\mathrm{Ca}$ & Total \\
\hline \multirow{4}{*}{$\begin{array}{l}\text { Egerbakta Q. } \\
\text { (Szarvaskő U.) }\end{array}$} & \multirow{2}{*}{$\begin{array}{l}\text { porphyry } \\
\text { albite }\end{array}$} & mean $(n=5)$ & 10.79 & 19.77 & 69.04 & b.d.l. & 0.12 & 99.63 & 0.91 & 1.02 & 3.01 & b.d.l. & 0.01 & 4.94 \\
\hline & & st.dev. & 0.39 & 0.16 & 0.37 & b.d.l. & 0.00 & 0.43 & 0.03 & 0.01 & 0.01 & b.d.l. & 0.00 & 0.02 \\
\hline & \multirow{2}{*}{$\begin{array}{l}\text { groundmass } \\
\text { albite }\end{array}$} & mean $(n=3)$ & 10.70 & 19.90 & 68.79 & b.d.1. & 0.20 & 99.46 & 0.90 & 1.02 & 3.00 & b.d.l. & 0.01 & 4.93 \\
\hline & & st.dev. & 0.28 & 0.16 & 0.21 & b.d.l. & 0.00 & 0.40 & 0.02 & 0.01 & 0.01 & b.d.1. & 0.00 & 0.02 \\
\hline \multirow{2}{*}{$\begin{array}{l}\text { Hruškovec Q. } \\
\text { (Kalnik Mts.) }\end{array}$} & \multirow{2}{*}{$\begin{array}{l}\text { groundmass } \\
\text { albite }\end{array}$} & mean $(n=5)$ & 9.92 & 20.01 & 69.23 & b.d.l. & 0.44 & 99.61 & 0.84 & 1.03 & 3.01 & b.d.l. & 0.02 & 4.90 \\
\hline & & st.dev. & 0.33 & 0.26 & 0.38 & b.d.l. & 0.19 & 0.31 & 0.03 & 0.01 & 0.01 & b.d.l. & 0.01 & 0.02 \\
\hline \multirow{4}{*}{$\begin{array}{l}\text { Mély Valley Q. } \\
\text { (Darnó U.) }\end{array}$} & \multirow{2}{*}{$\begin{array}{l}\text { porphyry } \\
\text { albite }\end{array}$} & mean $(n=6)$ & 10.51 & 20.22 & 68.13 & b.d.l. & 0.54 & 99.40 & 0.89 & 1.04 & 2.98 & b.d.l. & 0.03 & 4.95 \\
\hline & & st.dev. & 0.34 & 0.15 & 0.53 & b.d.l. & 0.17 & 0.29 & 0.03 & 0.01 & 0.01 & b.d.l. & 0.01 & 0.02 \\
\hline & \multirow{2}{*}{$\begin{array}{l}\text { groundmass } \\
\text { albite }\end{array}$} & mean $(n=4)$ & 9.86 & 20.13 & 68.92 & b.d.l. & 0.67 & 99.58 & 0.83 & 1.03 & 3.00 & b.d.1. & 0.03 & 4.90 \\
\hline & & st.dev. & 0.43 & 0.34 & 0.40 & b.d.l. & 0.09 & 0.28 & 0.04 & 0.01 & 0.01 & b.d.l. & 0.00 & 0.03 \\
\hline \multirow{2}{*}{$\begin{array}{l}\text { Nagy-Rézoldal } \\
\text { Q. (Darnó U.) }\end{array}$} & \multirow{2}{*}{$\begin{array}{l}\text { groundmass } \\
\text { albite }\end{array}$} & mean $(n=2)$ & 10.03 & 20.93 & 67.37 & b.d.l. & 1.48 & 99.81 & 0.85 & 1.08 & 2.95 & b.d.l. & 0.07 & 4.94 \\
\hline & & st.dev. & 0.27 & 0.41 & 1.03 & b.d.l. & 0.61 & 0.25 & 0.03 & 0.02 & 0.04 & b.d.l. & 0.03 & 0.04 \\
\hline \multirow[t]{2}{*}{$\begin{array}{l}\text { Stragopetra } \\
\text { Mts. }\end{array}$} & $\begin{array}{l}\text { porphyry } \\
\text { albite }\end{array}$ & $(n=1)$ & 10.32 & 19.50 & 68.01 & b.d.l. & 2.19 & 100.02 & 0.87 & 1.01 & 2.98 & b.d.l. & 0.10 & 4.96 \\
\hline & $\begin{array}{l}\text { groundmass } \\
\text { albite }\end{array}$ & $(n=1)$ & 9.34 & 20.51 & 68.00 & b.d.l. & 1.64 & 99.49 & 0.79 & 1.06 & 2.97 & b.d.l. & 0.08 & 4.90 \\
\hline \multirow[t]{4}{*}{ Vareš Q. } & \multirow{2}{*}{$\begin{array}{l}\text { porphyry } \\
\text { albite }\end{array}$} & mean $(n=6)$ & 10.11 & 20.06 & 68.91 & b.d.l. & 0.49 & 99.56 & 0.85 & 1.03 & 3.01 & b.d.1. & 0.02 & 4.91 \\
\hline & & st.dev. & 0.55 & 0.18 & 0.50 & b.d.l. & 0.12 & 0.28 & 0.05 & 0.01 & 0.01 & b.d.l. & 0.01 & 0.04 \\
\hline & \multirow{2}{*}{$\begin{array}{l}\text { ground- } \\
\text { mass albite }\end{array}$} & mean $(n=2)$ & 10.35 & 20.16 & 68.68 & 0.31 & 0.46 & 99.80 & 0.87 & 1.04 & 2.99 & 0.02 & 0.02 & 4.93 \\
\hline & & st.dev. & 0.18 & 0.37 & 0.47 & 0.00 & 0.08 & 0.02 & 0.01 & 0.02 & 0.01 & 0.00 & 0.00 & 0.01 \\
\hline
\end{tabular}

analyses are given in mass $\%$, while the cation numbers are calculated for 8 oxygene

b.d.1.: below detection limit; Q.: Quarry U.: Unit

Table 3.Results of the SEM-EDS studies (pyroxene analyses).

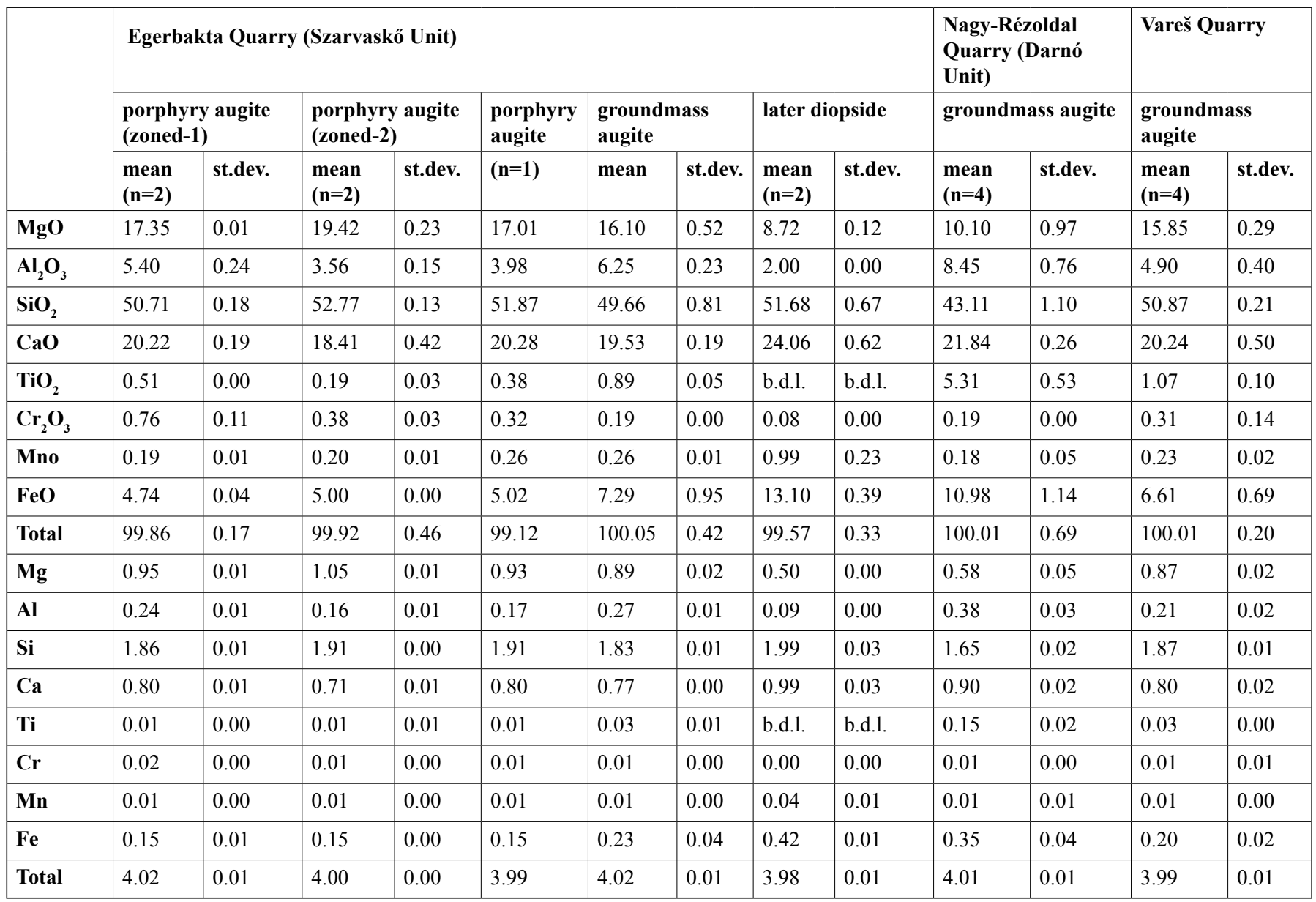

analyses are given in mass $\%$, while the cation numbers are calculated for 6 oxygene

b.d.1.: below detection limit 
Table 4. Results of the fluid inclusion study.

\begin{tabular}{|c|c|c|c|c|c|c|c|c|c|c|}
\hline $\begin{array}{l}\text { type of } \\
\text { infilling }\end{array}$ & locality & $\begin{array}{l}\text { number of } \\
\text { measure- } \\
\text { ments* }\end{array}$ & $\begin{array}{l}\text { Th } \\
\left(\text { mean },{ }^{\circ} \mathbf{C}\right)\end{array}$ & $\begin{array}{l}\text { scat- } \\
\text { tering } \\
\left({ }^{\circ} \mathrm{C}\right)\end{array}$ & $\begin{array}{l}\text { Te } \\
\text { (mean, } \\
\left.{ }^{\circ} \mathrm{C}\right)\end{array}$ & $\begin{array}{l}\text { scat- } \\
\text { tering } \\
\left({ }^{\circ} \mathrm{C}\right)\end{array}$ & $\begin{array}{l}\text { Tm } \\
\text { (mean, } \\
\text { C) }\end{array}$ & $\begin{array}{l}\text { scat- } \\
\text { tering } \\
\left({ }^{\circ} \mathrm{C}\right)\end{array}$ & $\begin{array}{l}\text { salinity } \\
\text { ( } \mathrm{NaCl} \text { equiv. } \\
\text { wt\%) }\end{array}$ & $\begin{array}{l}\text { scattering } \\
\text { (NaCl equiv. } \\
\text { wt.\%) }\end{array}$ \\
\hline \multirow[t]{2}{*}{$\begin{array}{l}\text { amygdales } \\
\text { of the closely } \\
\text { packed pillow }\end{array}$} & $\begin{array}{l}\text { Hosszú Valley } \\
\text { Quarry (Darnó } \\
\text { Unit) }\end{array}$ & 18 & 101 & 11 & -20.4 & & -2.73 & 0.36 & 4.54 & 0.55 \\
\hline & $\begin{array}{l}\text { Nagy-Rézoldal } \\
\text { Quarry (Darnó } \\
\text { Unit) }\end{array}$ & 32 & 136 & 19 & -21.6 & 0.65 & -2.10 & 0.40 & 3.49 & 0.62 \\
\hline \multirow[t]{2}{*}{$\begin{array}{l}\text { pyjamas-type } \\
\text { closely packed } \\
\text { pillow }\end{array}$} & $\begin{array}{l}\text { Hosszú Valley } \\
\text { Quarry (Darnó } \\
\text { Unit) }\end{array}$ & 25 & 91 & 14 & -21.3 & 0.82 & -2.70 & 0.42 & 4.49 & 0.65 \\
\hline & $\begin{array}{l}\text { Mély Valley Quarry } \\
\text { (Darnó Unit) }\end{array}$ & 37 & 92 & 13 & -22.2 & 0.82 & -3.30 & 1.00 & 5.33 & 1.50 \\
\hline $\begin{array}{l}\text { jig-saw veins } \\
\text { of the closely } \\
\text { packed pillow }\end{array}$ & $\begin{array}{l}\text { Hosszú Valley } \\
\text { Quarry (Darnó } \\
\text { Unit) }\end{array}$ & 22 & 110 & 18 & -21.3 & & -2.40 & 0.23 & 3.95 & 0.36 \\
\hline \multirow[t]{2}{*}{$\begin{array}{l}\text { interpillow } \\
\text { hyaloclastite } \\
\text { breccia }\end{array}$} & $\begin{array}{l}\text { Hosszú Valley } \\
\text { Quarry , earlier cal- } \\
\text { cite (Darnó Unit) }\end{array}$ & 10 & 98 & 16 & & & -1.90 & 0.14 & 3.20 & 0.23 \\
\hline & & 4 & 70 & 5 & & & -2.00 & 0.17 & 3.40 & 0.28 \\
\hline $\begin{array}{l}\text { pillow } \\
\text { fragmented } \\
\text { hyaloclastite } \\
\text { breccia }\end{array}$ & $\begin{array}{l}\text { Hosszú Valley } \\
\text { Quarry, later calcite } \\
\text { (Darnó Unit) }\end{array}$ & 27 & 88 & 13 & & & -1.79 & 0.22 & 3.04 & 0.36 \\
\hline
\end{tabular}

*: reveals to the no. of Th measurements. Te and Tm data may differ, see text for explanation.

Th: homogenisation temperature

Te: eutectic temperature

Tm: final melting temperature

albite in composition (Table 2, Fig. 3A), whereas the augite phenocrysts show compositional zoning due to slight variation in the $\mathrm{Ca}$ and $\mathrm{Mg}$ content (MORIMOTO, 1989; Table 3, Fig. 3B). Primary hydrothermal infillings are absent in the basalt, though the groundmass is altered to chlorite, clay minerals and calcite. Disseminated pyrite and chalcopyrite also occur in the altered ground mass. The XRPD analyses revealed the presence of chlorite-smectite, chlorite-illite interlayered clay minerals, celadonite and smectite. The Jurassic pillow basalt contains neither amygdales, nor jig-saw veins. Only a limited amount of hydrothermal mineral-cemented interpillow hyaloclastite breccia and cooling related thin, short veinlets occur (Fig. 2D).

\section{The peperitic pillow facies}

The peperitic pillow facies, which formed where the lava rocks were mixed with water soaked sediment (PALINKA ̌ et al., 2008, SKILLING et al., 2002), belong to the so-called blocky peperite subtype (SKILLING et al., 2002) at all the studied localities. This volcanic facies is characterised by $10-50 \mathrm{~cm}$ large basalt fragments (sometimes of pillow shape) in the matrix (50$70 \%$ ), which is a reddish limestone of Triassic age (Fig. 2E), whereas it is a fine grained, black siliciclastic rock in peperites of Jurassic age. The so-called fluidal peperite subtype (SKILLING et al., 2002) is locally present (Fig. 2E) and the transition from the closely packed pillow to the peperitic facies also occurs in the Triassic localities. The sedimentary material forms not only the matrix of the basalt fragments, but infiltrates into the cooling cracks of the basalt or forms a chaotic mixture with it (Fig. 2F). Where mixing of the volcanic material with unconsolidated sediments is the most chaotic, a high amount hydro- thermal minerals, such as calcite, quartz, chalcedony, chlorite, pumpellyite and laumontite is present as vein- or cavity-filling.

The texture of the Triassic limestone is generally micritic, but it locally contains bioclasts and weakly preserved Radiolarians, as well as fragments of Bivalve shells. The carbonate matrix characteristically contains disseminated minerals and fragments of basaltic origin (mostly plagioclase laths, glassy shards, rarely pyroxene, Fig. 2F). The limestone also contains disseminated, fine grained (below $3 \mu \mathrm{m}$ ) haematite laths and plates.

The siliciclastic sedimentary rock in the Jurassic peperites is completely altered to a fine grained mass of albite-quartz-chalcedony, but the original sedimentary textural features are preserved and resemble aleurolite.

In both cases, the mineralogical and textural features of basalt fragments admixed to the sediments are very similar to the basalt of the closely packed pillow facies, though more glassy parts, as well as haematitisation are more common in the Triassic basalts. The thin hydrothermal veinlets contain calcite, prehnite, quartz and chlorite in both occurrences. In addition, albite also occurs in the Jurassic peperite. The amygdales in the Triassic basalt contain calcite, chlorite and haematite, while the jig-saw veins are filled mostly with calcite, with some chlorite, laumontite and prehnite.

The in situ hyaloclastite breccia and the pillow fragmented hyaloclastite breccia facies

In the in situ hyaloclastite breccia facies only observed in localities of Triassic age, smaller fractured basalt pillows (20-30 $\mathrm{cm}$ ), and slightly disproportional pillow fragments, are cement- 
ed by hydrothermal calcite and cogenetic chlorite and pyrite. Glassy basalt shards and occasional pieces of reddish limestone fragments also occur. This facies forms close to the seafloor, immediately around the closely packed pillow facies (PALINKAŠ et al., 2008). It is a transitional facies between the closely packed pillow and the more distal pillow fragmented hyaloclastite breccia facies. The latter is observed at both Triassic and Jurassic localities and it contains more matrix and less and smaller basalt fragments than the in situ breccia (Fig. 2G). The hydrothermal cement is composed of quartz, chlorite, calcite, prehnite and pumpellyite. Basalt in both breccia facies is characterised with the same features as described above, however, more glassy textures are also common (Fig. 2H). The basalt is often strongly chloritised, but in the case of the Triassic ones, haematitisation also occurs.

\section{Fluid inclusion study}

Fluid inclusion studies were performed on calcite from the hydrothermal infillings. Microthermometric data from some Triassic and Jurassic localities are summarised in earlier publications (KISS et al., 2008, 2011, 2012). Here we present microthermometric data for the jig-saw veins, interpillow hyaloclastite breccia, the pillow fragmented hyaloclastite breccia and some new closely packed pillow occurrences. Interpretation is based on these new data together with that previously published.

In all cases, the calcite often shows a spongy texture, making observation of the peculiarities of fluid inclusions difficult. Primary fluid inclusions are characterised by a negative crystal shape and are very rare, occurring in isolation in the inclusion poor parts of calcite or in populations of randomly distributed inclusions forming " $3 \mathrm{D}$ clouds" in some parts of the host minerals, far from the cleavage-plane related secondary fractures. The size of primary inclusions is generally between $4-10 \mu \mathrm{m}$, while the phase ratio with $95-90 \%$ liquid phase and $5-10 \%$ vapour phase appear to be constant, suggesting homogenous entrapment from a homogenous parent fluid. The small size of the inclusions, as well as the generally occurring metastable melting during freezing runs resulted in a low amount of microthermometry data.

Figures 5-8. and Table 4. present the results obtained from the amygdale filling calcite, the mineral bands of the pyjamatype pillows, the jig-saw veins, the interpillow hyaloclastite breccia as well as the pillow fragmented hyaloclastite breccia of the Triassic localities.

\section{Chlorite thermometry}

Temperatures of fluid-rock interaction were estimated on the basis of chlorite thermometry from samples of Triassic and Jurassic age. Compositions of chlorite occurring in the groundmass of basalt, forming pseudomorphs after olivine, infilling amygdales and veins and confined to the cement of the interpillow and the pillow fragmented hyaloclastite breccia, were determined by electron microprobe analyses. Results indicate that all chlorite samples belong to the Type I, Mg-chlorite group, defined by ZANE \& WEISS (1998). Table 5. shows the compositions and calculated formation temperatures of chlorite crystals of different textural positions (CHATELINEAU \& IZQUIERDO, 1988 and ZANG \& FYFE, 1995).

\section{Geochemical features of the fluid/rock interaction}

The results of the analyses for most major elements $(\mathrm{Ca}, \mathrm{Mg}$, $\mathrm{Na}, \mathrm{K}, \mathrm{Fe}, \mathrm{Mn}$ ) as well as some precious and base metal trace elements (e.g. $\mathrm{Au}, \mathrm{Cu}, \mathrm{Zn}$ ) and the LILE group of trace elements show highly variable amounts and scattering on the spider diagram. In contrast, $\mathrm{Si}, \mathrm{Al}, \mathrm{Cr}, \mathrm{Ti}$, the HFS and REE group of trace elements do not scatter significantly, when comparing the less and more altered samples in our database (Table 6 and Fig. 9 A, B, C, D).

As a consequence, the spider diagram of the REE shows two narrow, distinguishable fields of results, one for the Triassic and one for the Jurassic basalts (Fig. 9 C, D). Enrichment in LREE, thus a higher $\mathrm{La} / \mathrm{Sm}$ ratio (above 1) is characteristic for the Triassic basalts, while a lower $\mathrm{La} / \mathrm{Sm}$ ratio (around or below 1) is typical for the Jurassic basalts indicating their different origins (WILSON, 1989). This topic has been exhaustively discussed in previous publications (see e.g. KISS et al., 2011, 2012 and references therein), therefore the data is evaluated herein terms of the fluid/rock interactions, with daigrams presented only for comparison with the earlier results.

Discrimination diagrams based on rather immobile elements by PEARCE \& CANN (1973) and MESCHEDE (1986) prove the different geotectonic position of the basaltic rocks of Triassic and Jurassic ages (Fig. 9EF). Enrichment in the incompatible elements in the Triassic basalt shows relatively low partial melting, which together with the high $\mathrm{Zr} / \mathrm{Y}$ ratio (generally above 4) supports the idea that this basalt is not related to mid-oceanic ridges (SUN \& MCDONOUGH, 1989).

Geochemical analyses of the peperitic limestone are shown in Table 7.

Mass transfer calculation (MTC, GRANT, 1986, MACLEAN \& KRANIDIOTIS, 1987, BRAUHART et al., 2001, ULRICH \& HEINRICH, 2002), which is widely accepted in ore deposit exploration, can also efficiently be used for quantitative modelling of element mobilisation occurring during submarine hydrothermal fluid-rock interaction processes. The calculations may be done on different scales; within a single pillow (from its centre to its margin), within a volcanic facies (from less to more altered parts) and for comparison of two or more volcanic facies. The present study shows the preliminary results of these calculations; a few examples for all these different scales.

According to the MTC method, after determining the freshest samples in the data set, the most immobile components have to be determined. In the present study, we used the isocon method and thus $\mathrm{Y}, \mathrm{Zr}, \mathrm{Nb}$ and $\mathrm{TiO}_{2}$ were found to be the most immobile components. Then the residual compositions of the altered samples were calculated, followed by determination of the gains/losses of mass. Only data sets originating from the same locality (thus rocks from the same protoliths) were compared and used for MTC calculations (Fig. 10). Generally, a decrease in $\mathrm{SiO}_{2}, \mathrm{CaO}$ and the analysed metals and a slight increase in $\mathrm{Na}_{2} \mathrm{O}$ and $\mathrm{K}_{2} \mathrm{O}$ are observable independently of the scale of observation. Special features may be also identified (e.g. the amount of mass transfered is significantly higher when heading to the peperitic facies; see Fig. 10). 
Table 5. Results of the EPMA quantitative analyses of the chlorite crystals.

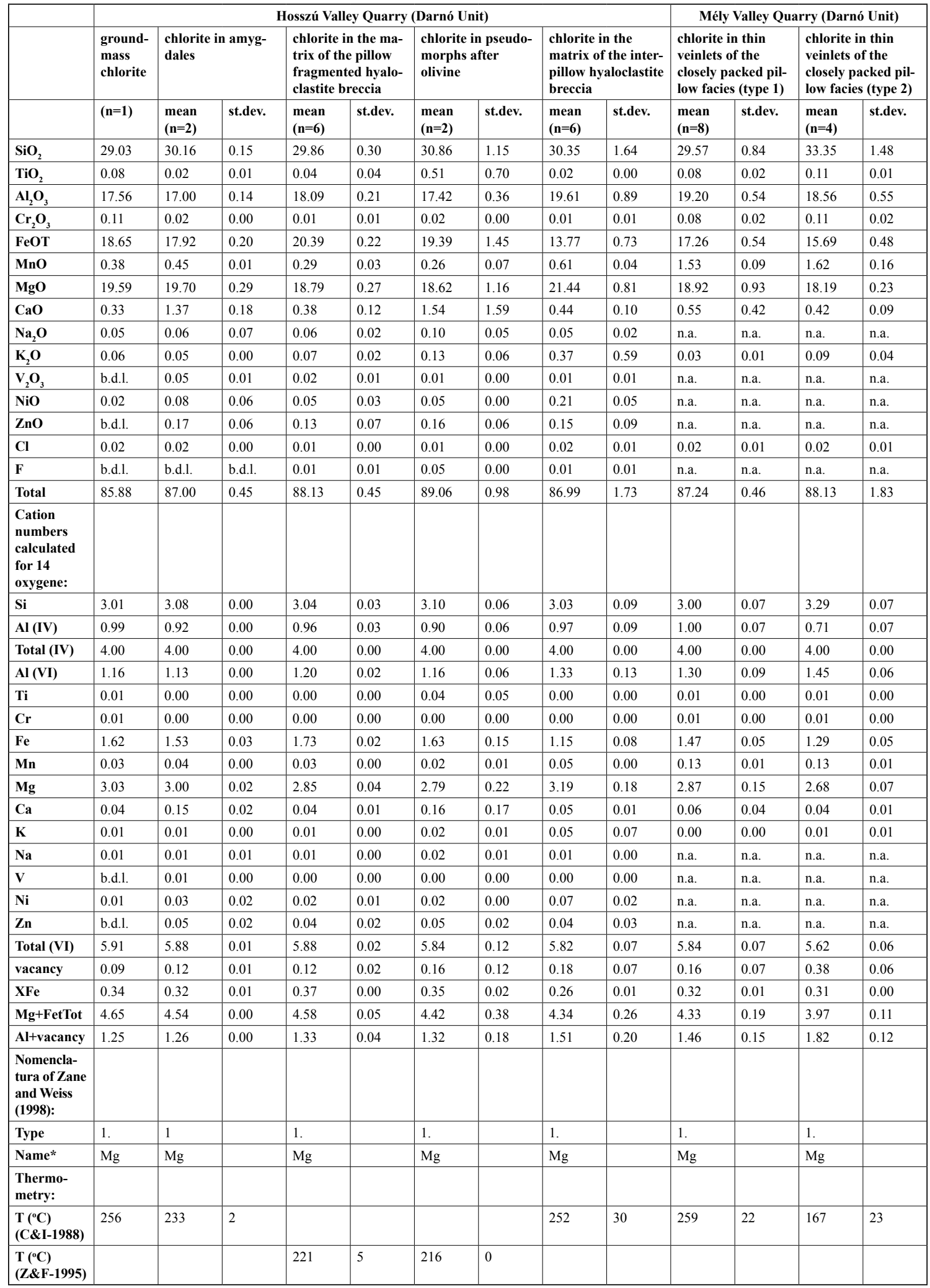

Analyses are given in mass $\%$

*: Mg: magnesium chlorite

Thermometry based on C\&I-1988: Chatelineau and Izquierdo, 1988; Z\&F-1995: Zang and Fyfe, 1995

**: though slightly differers from the criteria of the given method, based on Frimmel (1997) the data still can be used for calculations.

(n.a.: not available; b.d.1.: below detection limit, st.dev.: standard deviation)

***: only one analyses fit into the criteria of the thermometry methods, therefore mean and standard deviation were not calculated. 
Table 5. Results of the EPMA quantitative analyses of the chlorite crystals.

\begin{tabular}{|c|c|c|c|c|c|c|c|c|c|c|c|c|c|c|c|c|}
\hline & \multicolumn{14}{|c|}{ Nagy-Rézoldal Quarry (Darnó Unit) } & \multirow{2}{*}{\multicolumn{2}{|c|}{\begin{tabular}{|l|} 
Stragopetra Mts. \\
chlorite in thin \\
veinlets of the \\
closely packed \\
pillow facies \\
\end{tabular}}} \\
\hline & \multicolumn{2}{|c|}{$\begin{array}{l}\text { chlorite in small } \\
\text { (only chlorite } \\
\text { filled) amygdales }\end{array}$} & \multicolumn{2}{|c|}{$\begin{array}{l}\text { chlorite in small } \\
\text { amygdales }\end{array}$} & \multicolumn{2}{|c|}{$\begin{array}{l}\text { groundmass } \\
\text { chlorite }\end{array}$} & \multicolumn{2}{|c|}{$\begin{array}{l}\text { chlorite in pseu- } \\
\text { domorphs after } \\
\text { olivine }\end{array}$} & \multicolumn{2}{|c|}{$\begin{array}{l}\text { chlorite in thin } \\
\text { veinlets of the } \\
\text { closely packed } \\
\text { pillow facies }\end{array}$} & \multicolumn{2}{|c|}{$\begin{array}{l}\text { chlorite on the } \\
\text { rims of the big } \\
\text { amygdales }\end{array}$} & \multicolumn{2}{|c|}{$\begin{array}{l}\text { chlorite on the } \\
\text { rims of the jig-saw } \\
\text { veins }\end{array}$} & & \\
\hline & $\begin{array}{l}\text { mean } \\
(n=13)\end{array}$ & st.dev. & $\begin{array}{l}\text { mean } \\
(\mathrm{n}=3)\end{array}$ & st.dev. & $\begin{array}{l}\text { mean } \\
(\mathrm{n}=3)\end{array}$ & st.dev. & $\begin{array}{l}\text { mean } \\
(\mathrm{n}=3)\end{array}$ & st.dev. & $\begin{array}{l}\text { mean } \\
(\mathrm{n}=2)\end{array}$ & st.dev. & $\begin{array}{l}\text { mean } \\
(\mathrm{n}=3)\end{array}$ & st.dev. & $\begin{array}{l}\text { mean } \\
(\mathrm{n}=3)\end{array}$ & st.dev. & $\begin{array}{l}\text { mean } \\
(\mathrm{n}=3)\end{array}$ & st.dev. \\
\hline $\mathrm{SiO}_{2}$ & 30.53 & 0.42 & 30.60 & 0.25 & 31.33 & 1.85 & 28.94 & 0.30 & 29.73 & 0.73 & 29.60 & 0.64 & 30.10 & 0.90 & 26.97 & 1.74 \\
\hline $\mathrm{TiO}_{2}$ & 0.02 & 0.01 & 0.01 & 0.00 & 0.03 & 0.01 & 0.02 & 0.01 & 0.02 & 0.00 & 0.01 & 0.00 & 0.02 & 0.00 & 0.02 & 0.00 \\
\hline $\mathrm{Al}_{2} \mathrm{O}_{3}$ & 16.78 & 0.42 & 17.19 & 0.15 & 17.09 & 0.88 & 18.46 & 0.45 & 17.82 & 0.54 & 18.14 & 0.51 & 18.12 & 0.77 & 17.26 & 0.68 \\
\hline $\mathrm{Cr}_{2} \mathrm{O}_{3}$ & 0.09 & 0.05 & 0.03 & 0.01 & 0.08 & 0.01 & 0.11 & 0.04 & 0.03 & 0.01 & 0.03 & 0.01 & 0.02 & 0.01 & 0.01 & 0.00 \\
\hline FeOT & 20.74 & 0.42 & 20.98 & 0.25 & 22.88 & 1.40 & 24.08 & 0.51 & 23.41 & 0.04 & 23.57 & \begin{tabular}{|l|}
0.09 \\
\end{tabular} & 23.72 & 0.27 & 23.25 & 1.36 \\
\hline MnO & 0.32 & 0.05 & 0.34 & 0.04 & 0.26 & 0.07 & 0.26 & 0.03 & 0.30 & 0.04 & 0.26 & 0.05 & 0.28 & 0.04 & 0.57 & 0.02 \\
\hline MgO & 16.67 & 0.35 & 16.63 & 0.14 & 16.60 & 0.16 & 16.24 & 0.53 & 17.04 & 0.66 & 16.68 & 0.35 & 16.49 & 0.86 & 15.14 & 0.47 \\
\hline $\mathrm{CaO}$ & 0.31 & 0.03 & 0.33 & 0.01 & 0.40 & 0.13 & 0.21 & 0.03 & 0.27 & 0.02 & 0.22 & 0.04 & 0.24 & 0.04 & 2.23 & 2.03 \\
\hline $\mathrm{Na}_{2} \mathrm{O}$ & n.a. & n.a. & n.a. & n.a. & 0.10 & 0.08 & 0.03 & 0.02 & 0.06 & 0.01 & 0.01 & 0.00 & 0.06 & 0.01 & 0.06 & 0.05 \\
\hline $\mathbf{K}_{2} \mathrm{O}$ & 0.01 & 0.01 & 0.02 & 0.01 & 0.05 & 0.03 & 0.09 & 0.06 & 0.04 & 0.00 & 0.03 & 0.01 & 0.15 & 0.21 & 0.14 & 0.13 \\
\hline $\mathrm{V}_{2} \mathrm{O}_{3}$ & n.a. & n.a. & n.a. & n.a. & 0.03 & 0.02 & 0.03 & 0.02 & 0.01 & 0.01 & 0.02 & 0.01 & 0.02 & 0.01 & 0.03 & 0.01 \\
\hline $\mathrm{NiO}$ & n.a. & n.a. & n.a. & n.a. & 0.07 & 0.04 & 0.05 & 0.01 & 0.04 & 0.01 & 0.06 & 0.01 & 0.06 & 0.04 & 0.05 & 0.02 \\
\hline $\mathrm{ZnO}$ & n.a. & n.a. & n.a. & n.a. & 0.14 & 0.12 & 0.10 & 0.09 & 0.08 & 0.06 & 0.08 & 0.08 & 0.06 & 0.00 & 0.15 & 0.07 \\
\hline $\mathrm{Cl}$ & 0.01 & 0.01 & 0.02 & 0.01 & 0.02 & 0.01 & b.d.l. & b.d.1. & 0.02 & 0.00 & 0.02 & 0.00 & 0.01 & 0.00 & 0.02 & 0.01 \\
\hline $\mathbf{F}$ & n.a. & n.a. & n.a. & n.a. & b.d.l. & b.d.l. & b.d.l. & b.d.l. & b.d.1. & 0.00 & b.d.l. & b.d.1. & b.d.1. & b.d.1. & 0.01 & 0.00 \\
\hline Total & 85.46 & 0.94 & 86.13 & 0.02 & 89.05 & 0.44 & 88.58 & 0.77 & 88.79 & 0.71 & 88.66 & 0.49 & 89.25 & 0.27 & 85.82 & 1.31 \\
\hline \multicolumn{17}{|l|}{$\begin{array}{l}\text { Cation } \\
\text { numbers } \\
\text { calculated } \\
\text { for } 14 \\
\text { oxygene: }\end{array}$} \\
\hline $\mathrm{Si}$ & 3.20 & 0.03 & 3.18 & 0.02 & 3.18 & 0.16 & 2.99 & 0.01 & 3.05 & 0.04 & 3.04 & 0.05 & 3.07 & 0.08 & 2.91 & 0.12 \\
\hline $\mathrm{Al}$ (IV) & 0.80 & 0.03 & 0.82 & 0.02 & 0.82 & 0.16 & 1.01 & 0.01 & 0.95 & 0.04 & 0.97 & 0.04 & 0.93 & 0.08 & 1.09 & 0.12 \\
\hline Total (IV) & 4.00 & 0.00 & 4.00 & 0.00 & 4.00 & 0.00 & 4.00 & 0.00 & 4.00 & 0.00 & 4.00 & 0.00 & 4.00 & 0.00 & 4.00 & 0.00 \\
\hline $\mathrm{Al}(\mathrm{VI})$ & 1.27 & 0.03 & 1.29 & 0.01 & 1.23 & 0.04 & 1.23 & 0.06 & 1.20 & 0.04 & 1.23 & 0.03 & 1.24 & 0.06 & 1.11 & 0.14 \\
\hline $\mathrm{Ti}$ & 0.00 & 0.00 & 0.00 & 0.00 & 0.00 & 0.00 & 0.00 & 0.00 & 0.00 & 0.00 & 0.00 & 0.00 & 0.00 & 0.00 & 0.00 & 0.00 \\
\hline $\mathrm{Cr}$ & 0.01 & 0.00 & 0.00 & 0.00 & 0.01 & 0.00 & 0.01 & 0.00 & 0.00 & 0.00 & 0.00 & 0.00 & 0.00 & 0.00 & 0.00 & 0.00 \\
\hline $\mathrm{Fe}$ & 1.82 & 0.02 & 1.82 & 0.03 & 1.94 & 0.14 & 2.08 & 0.03 & 2.01 & 0.02 & 2.02 & 0.02 & 2.02 & 0.04 & 2.10 & 0.12 \\
\hline Mn & 0.03 & 0.00 & 0.03 & 0.00 & 0.02 & 0.01 & 0.02 & 0.00 & 0.03 & 0.00 & 0.02 & 0.00 & 0.02 & 0.00 & 0.05 & 0.00 \\
\hline Mg & 2.60 & 0.04 & 2.58 & 0.02 & 2.51 & 0.01 & 2.50 & 0.06 & 2.60 & 0.07 & 2.55 & 0.04 & 2.50 & 0.12 & 2.44 & 0.05 \\
\hline $\mathrm{Ca}$ & 0.03 & 0.00 & 0.04 & 0.00 & 0.04 & 0.01 & 0.02 & 0.00 & 0.03 & 0.00 & 0.02 & 0.00 & 0.03 & 0.00 & 0.26 & 0.24 \\
\hline $\mathbf{K}$ & 0.00 & 0.00 & 0.00 & 0.00 & 0.01 & 0.00 & 0.01 & 0.01 & 0.01 & 0.00 & 0.00 & 0.00 & 0.02 & 0.03 & 0.02 & 0.02 \\
\hline $\mathbf{N a}$ & n.a. & n.a. & n.a. & n.a. & 0.02 & 0.01 & 0.01 & 0.00 & 0.01 & 0.00 & 0.00 & 0.00 & 0.01 & 0.00 & 0.01 & 0.01 \\
\hline $\mathbf{V}$ & n.a. & n.a. & n.a. & n.a. & 0.00 & 0.00 & 0.00 & 0.00 & 0.00 & 0.00 & 0.00 & 0.00 & 0.00 & 0.00 & 0.00 & 0.00 \\
\hline $\mathbf{N i}$ & n.a. & n.a. & n.a. & n.a. & 0.02 & 0.01 & 0.02 & 0.00 & 0.01 & 0.00 & 0.02 & 0.00 & 0.02 & 0.01 & 0.02 & 0.01 \\
\hline $\mathrm{Zn}$ & n.a. & n.a. & n.a. & n.a. & 0.04 & 0.04 & 0.03 & 0.03 & 0.02 & 0.02 & 0.02 & 0.02 & 0.02 & 0.00 & 0.05 & 0.02 \\
\hline Total (VI) & 5.76 & 0.02 & 5.76 & 0.01 & 5.79 & 0.09 & 5.88 & 0.03 & 5.88 & 0.00 & 5.86 & 0.02 & 5.85 & 0.04 & 5.99 & 0.13 \\
\hline vacancy & 0.24 & 0.02 & 0.24 & 0.01 & 0.21 & 0.09 & 0.12 & 0.03 & 0.12 & 0.00 & 0.14 & 0.02 & 0.15 & 0.04 & 0.01 & 0.13 \\
\hline $\mathrm{XFe}$ & 0.41 & 0.00 & 0.41 & 0.00 & 0.43 & 0.02 & 0.45 & 0.00 & 0.43 & 0.01 & 0.44 & 0.01 & 0.44 & 0.01 & 0.43 & 0.02 \\
\hline Mg+FetTot & 4.42 & 0.05 & 4.40 & 0.02 & 4.46 & 0.15 & 4.58 & 0.09 & 4.61 & 0.05 & 4.57 & 0.03 & 4.53 & 0.10 & 4.54 & 0.17 \\
\hline Al+vacancy & 1.51 & 0.05 & 1.53 & 0.02 & 1.44 & 0.13 & 1.35 & 0.09 & 1.32 & 0.05 & 1.37 & 0.03 & 1.39 & 0.07 & 1.11 & 0.27 \\
\hline \multicolumn{17}{|l|}{$\begin{array}{l}\text { Nomencla- } \\
\text { tura of Zane } \\
\text { and Weiss } \\
\text { (1998): }\end{array}$} \\
\hline Type & 1. & & 1. & & 1. & & 1. & & 1. & & 1. & & 1. & & 1. & \\
\hline Name* & $\mathrm{Mg}$ & & $\mathrm{Mg}$ & & $\mathrm{Mg}$ & & $\mathrm{Mg}$ & & $\mathrm{Mg}$ & & $\mathrm{Mg}$ & & $\mathrm{Mg}$ & & $\mathrm{Mg}$ & \\
\hline \multicolumn{17}{|l|}{$\begin{array}{l}\text { Thermo- } \\
\text { metry: }\end{array}$} \\
\hline \multicolumn{17}{|l|}{$\begin{array}{l}\left.\text { T ( }{ }^{\circ} \mathrm{C}\right) \\
(\mathrm{C} \& \mathrm{I}-1988)\end{array}$} \\
\hline $\begin{array}{l}\left.\text { T ( }{ }^{\circ} \mathrm{C}\right) \\
(\mathrm{Z} \& \mathrm{~F}-1995)\end{array}$ & $174 * *$ & 25 & $185^{* *}$ & 4 & $221 * * *$ & & 223 & 2 & 212 & 4 & 213 & 9 & 215 & 9 & 240 & 26 \\
\hline
\end{tabular}

Analyses are given in mass $\%$

*: Mg: magnesium chlorite

Thermometry based on C\&I-1988: Chatelineau and Izquierdo, 1988; Z\&F-1995: Zang and Fyfe, 1995

**: though slightly differers from the criteria of the given method, based on Frimmel (1997) the data still can be used for calculations.

(n.a.: not available; b.d.l.: below detection limit, st.dev.: standard deviation)

***: only one analyses fit into the criteria of the thermometry methods, therefore mean and standard deviation were not calculated. 


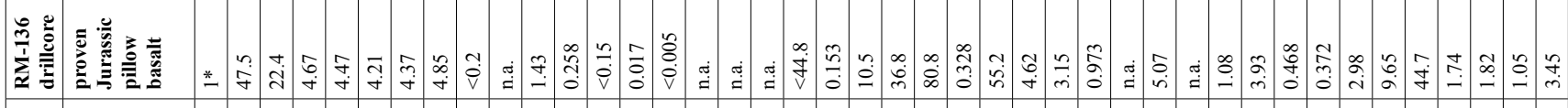

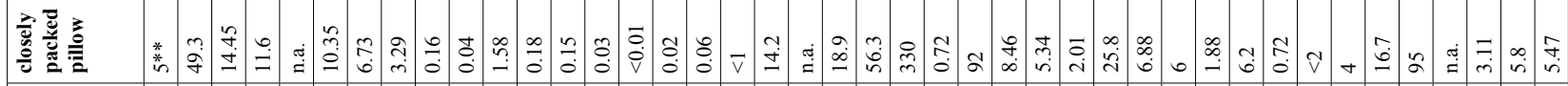

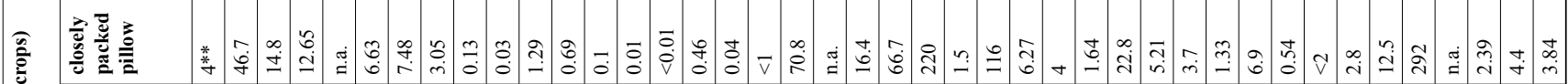

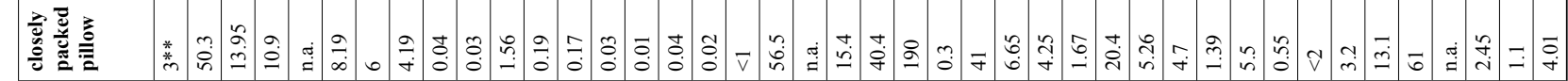

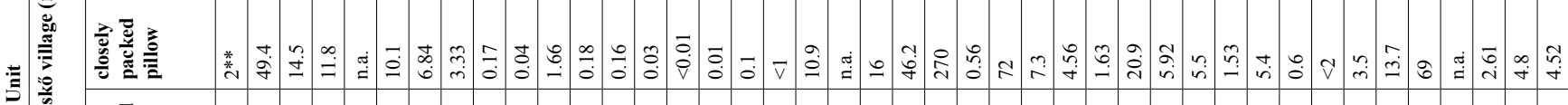

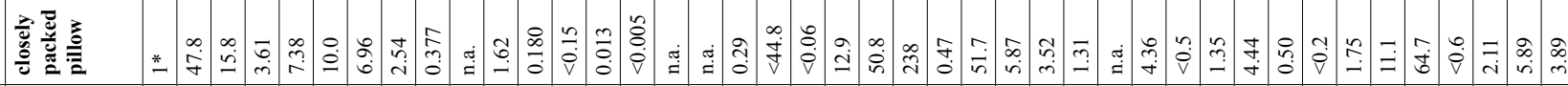

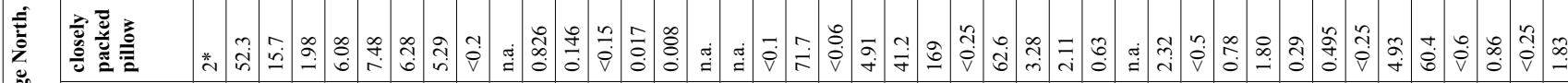

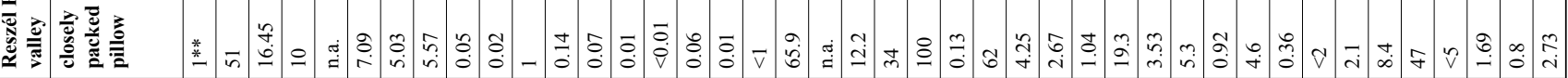

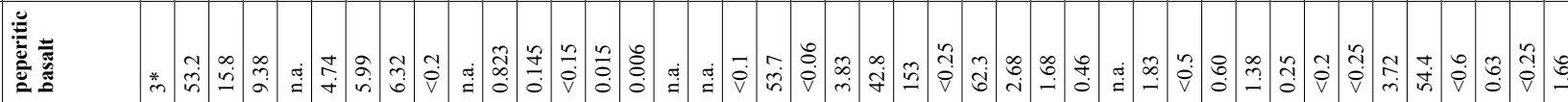

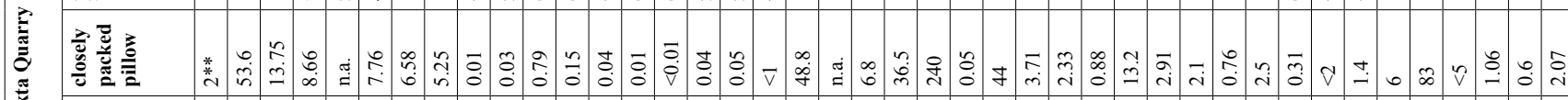

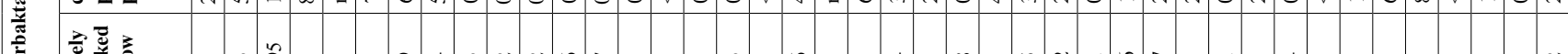

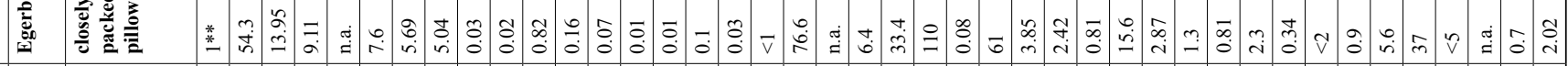

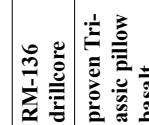

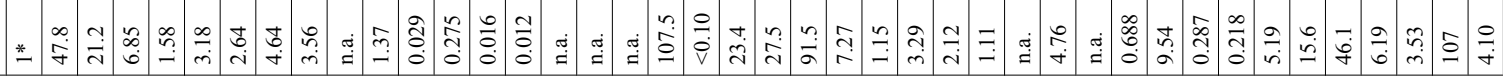

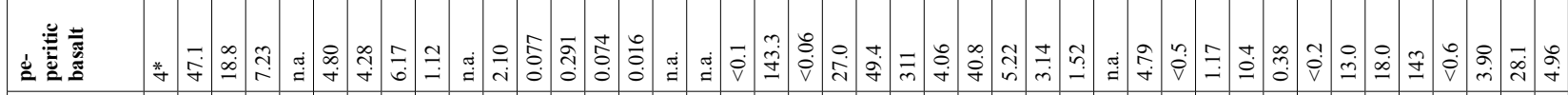

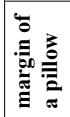
*

要

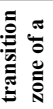

(

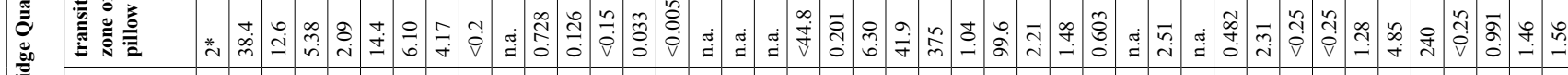

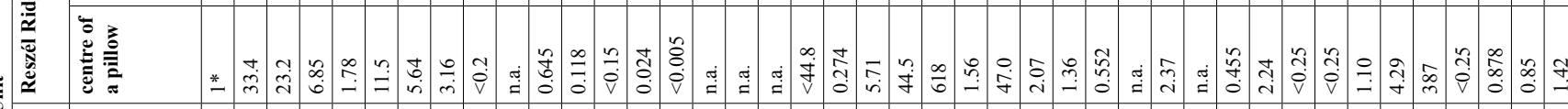

5

焉离

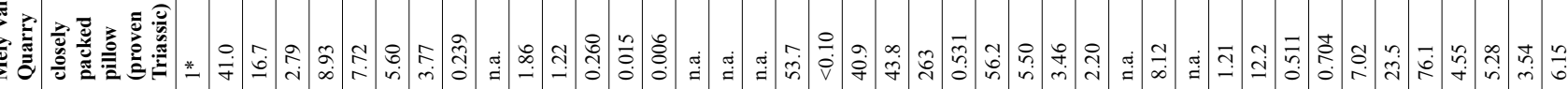

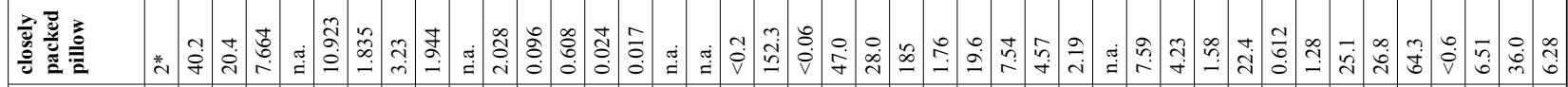

垔

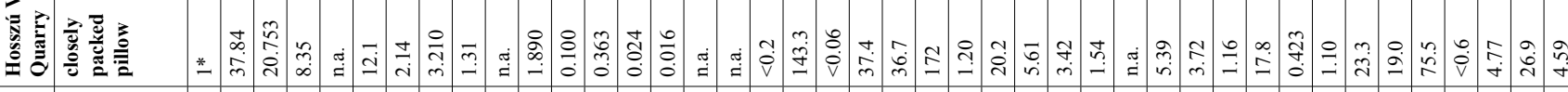

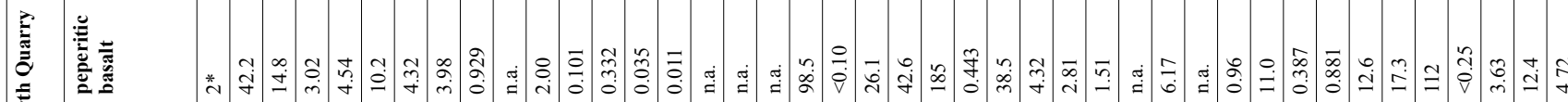

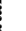

窟

产

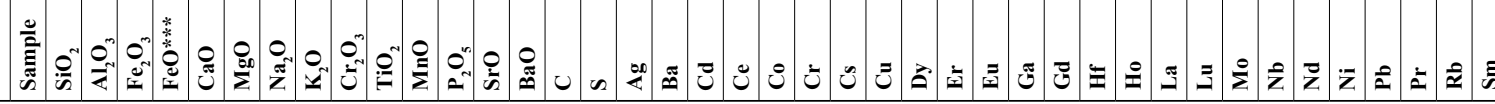




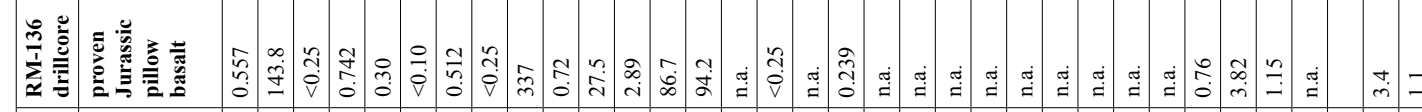

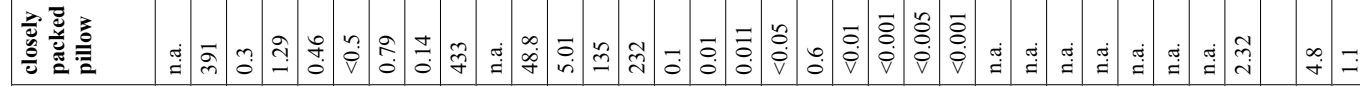

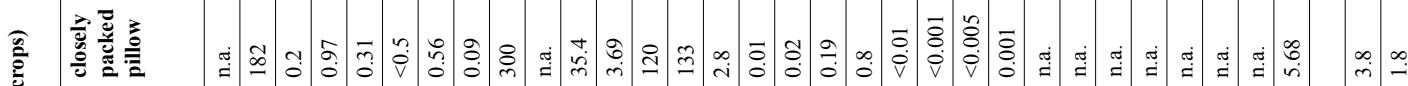

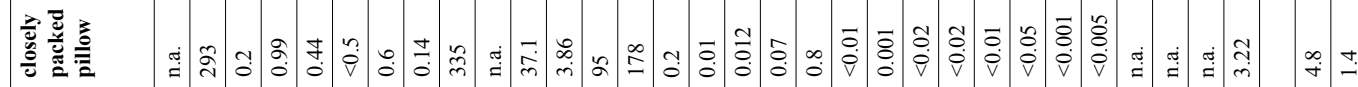

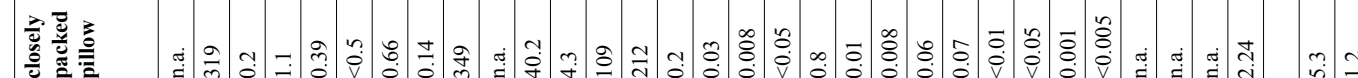

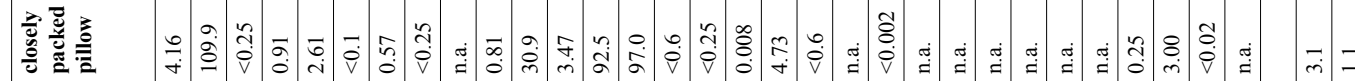
(n)

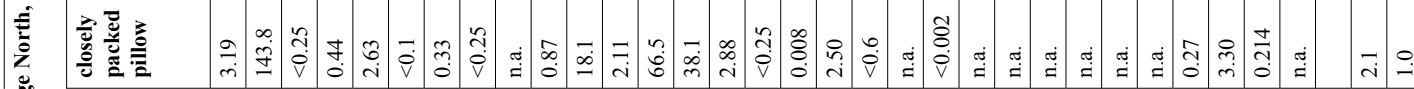
望

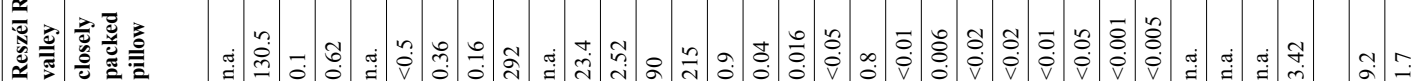

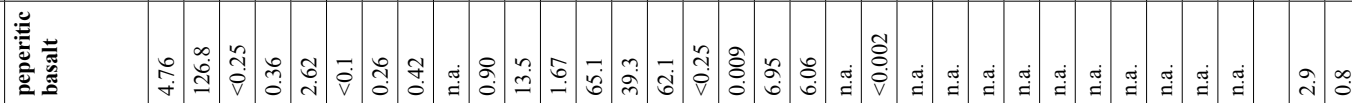

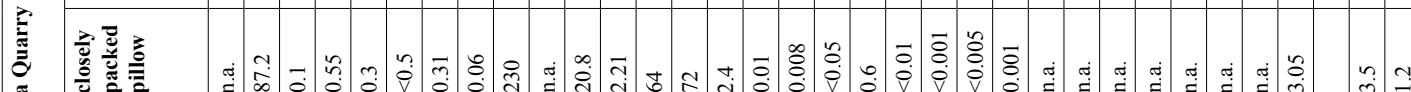

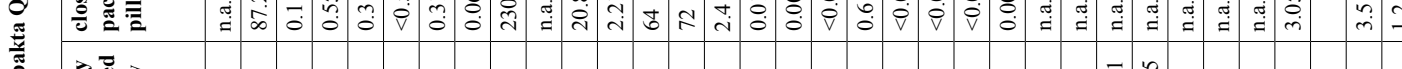

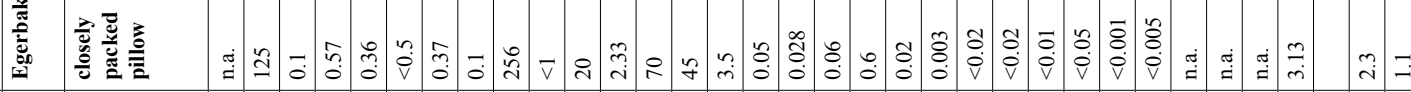

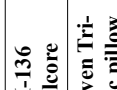

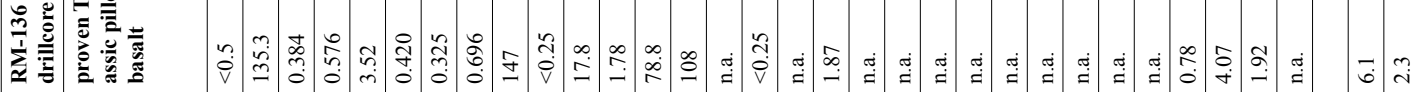

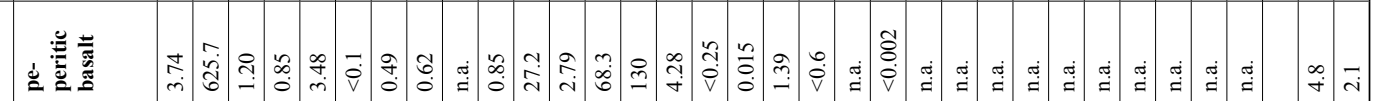

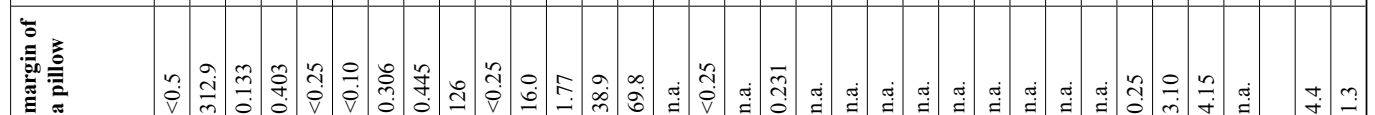

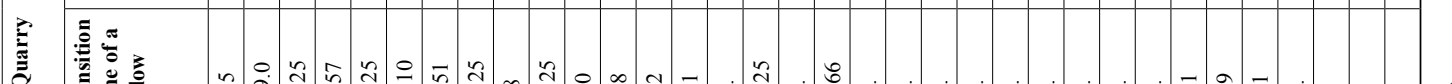

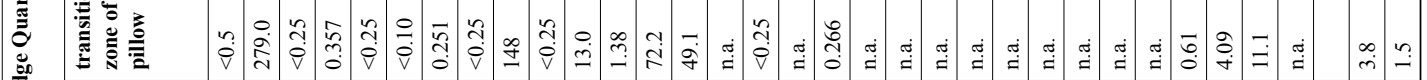
要

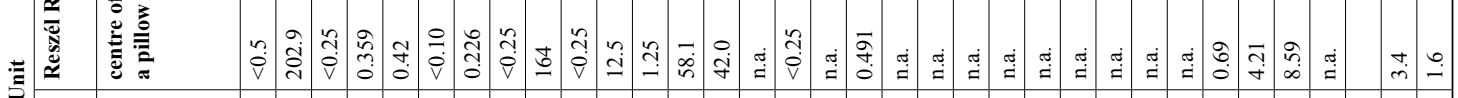
(1)

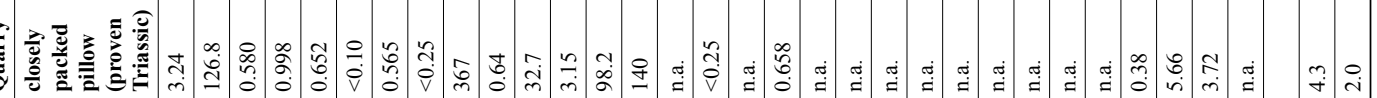

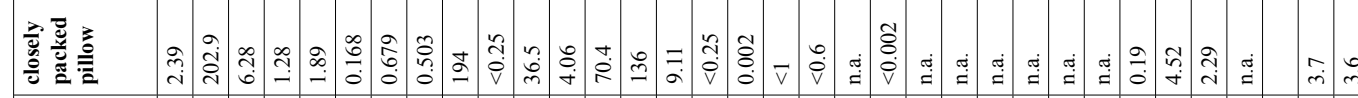
政

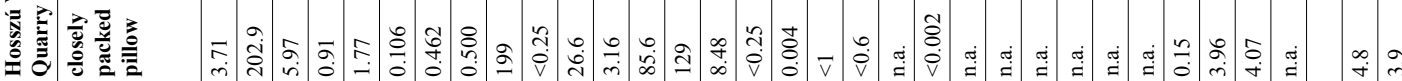

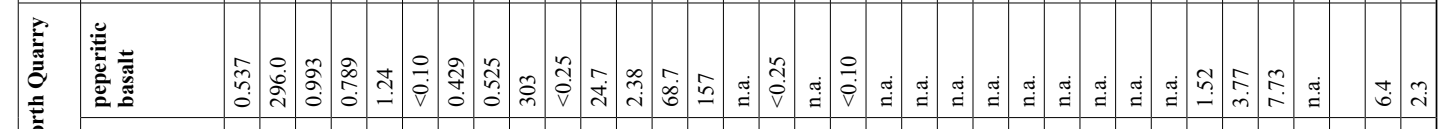
言 ₹ 䆛 苞. 产总 巡 눙융

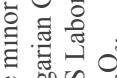

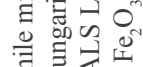

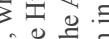

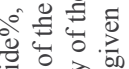

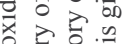

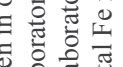

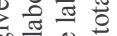
品 嗐 $\Xi$ 흄휴 西

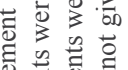

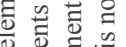
흘

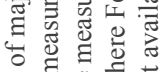
을 올 
Table 7. Results of the geochemical analyses (limestone).

\begin{tabular}{|c|c|c|}
\hline & \multicolumn{2}{|c|}{ Darnó Unit } \\
\hline Locality & Báj-patak N Q. & Reszél Ridge Q. \\
\hline Rock type & $\begin{array}{l}\text { red limestone } \\
\text { (peperitic facies) }\end{array}$ & $\begin{array}{l}\text { red limestone (peperitic } \\
\text { facies) }\end{array}$ \\
\hline Sample & $1 *$ & $1 *$ \\
\hline $\mathrm{SiO}_{2}$ & 26.7 & 7.64 \\
\hline $\mathrm{Al}_{2} \mathrm{O}_{3}$ & 5.08 & 5.17 \\
\hline $\mathrm{Fe}_{2} \mathrm{O}_{3}$ & 29.5 & 43.2 \\
\hline $\mathrm{FeO}^{* *}$ & 5.85 & n.a. \\
\hline $\mathrm{CaO}$ & 13.7 & 22.5 \\
\hline MgO & 3.22 & 1.05 \\
\hline $\mathrm{Na}_{2} \mathrm{O}$ & 0.230 & 0.564 \\
\hline $\mathrm{K}_{2} \mathrm{O}$ & $<0.2$ & $<0.2$ \\
\hline $\mathrm{TiO}_{2}$ & 0.093 & 0.124 \\
\hline MnO & 0.116 & 0.085 \\
\hline $\mathbf{P}_{2} \mathbf{O}_{5}$ & 0.277 & 0.317 \\
\hline SrO & 0.006 & 0.014 \\
\hline $\mathrm{BaO}$ & $<0.005$ & 0.005 \\
\hline Ag & n.a. & $<0.25$ \\
\hline Ba & $<44.8$ & 44.8 \\
\hline Cd & 0.244 & $<0.06$ \\
\hline $\mathrm{Ce}$ & 6.13 & 5.17 \\
\hline Co & 8.48 & 22.0 \\
\hline $\mathrm{Cr}$ & 14.5 & 7.29 \\
\hline Cs & 1.61 & $<0.625$ \\
\hline $\mathbf{C u}$ & 6.10 & $<0.2$ \\
\hline Dy & 0.91 & 0.59 \\
\hline Er & 0.55 & 0.34 \\
\hline Eu & 0.365 & 0.13 \\
\hline Gd & 1.27 & 0.56 \\
\hline Hf & n.a. & $<1.25$ \\
\hline Ho & 0.188 & $<0.125$ \\
\hline La & 4.10 & 2.89 \\
\hline $\mathbf{L u}$ & $<0.25$ & $<0.125$ \\
\hline Mo & 1.60 & $<0.2$ \\
\hline
\end{tabular}

Analyses of the major elements are given in oxide $\%$,

while minor and trace elements are given in $\mathrm{ppm}$.

*: The measurements were undertaken in the laboratory of the

Hungarian Geological Institute.

**: Where $\mathrm{FeO}$ is not given, the total amount of $\mathrm{Fe}$ is

given as $\mathrm{Fe}_{2} \mathrm{O}_{3}$.

n.a.: not available

\section{DISCUSSION}

\section{Temporal evolution of fluid-rock interactions}

The submarine basaltic rocks of Triassic and Jurassic ages from localities in this study area were not formed in a typical mid-oceanic ridge setting (AIGNER-TORRES \& KOLLER, 1999, BALLA et al., 1980, BUDA \& KISS, 1980, CSONTOS, 2000, KOVÁCS et al., 2008, 2010, KISS et al., 2008, 2010, 2011, 2012), thus, widely used models for hydrothermal fluid circulation in ophiolitic sequences of oceanic ridges (see e.g. FOUSTOUKOS \& SEY-

\begin{tabular}{|c|c|c|}
\hline & \multicolumn{2}{|c|}{ Darnó Unit } \\
\hline Locality & Báj-patak N Q. & Reszél Ridge Q. \\
\hline Rock type & $\begin{array}{l}\text { red limestone } \\
\text { (peperitic facies) }\end{array}$ & $\begin{array}{l}\text { red limestone (peperitic } \\
\text { facies) }\end{array}$ \\
\hline $\mathbf{N b}$ & 0.203 & $<0.625$ \\
\hline Nd & 3.42 & 3.34 \\
\hline $\mathbf{N i}$ & 62.8 & 136 \\
\hline $\mathbf{P b}$ & $<0.25$ & 14.3 \\
\hline Pr & 0.761 & 0.80 \\
\hline $\mathbf{R b}$ & 0.81 & $<0.625$ \\
\hline Sm & 0.824 & 0.73 \\
\hline Sn & $<0.5$ & 3.61 \\
\hline $\mathrm{Sr}$ & 50.7 & 118.4 \\
\hline Ta & $<0.25$ & $<0.625$ \\
\hline $\mathbf{T b}$ & 0.144 & $<0.125$ \\
\hline Th & $<0.25$ & 2.63 \\
\hline Tl & $<0.10$ & $<0.25$ \\
\hline Tm & $<0.10$ & $<0.125$ \\
\hline $\mathbf{U}$ & 0.545 & $<0.625$ \\
\hline $\mathbf{V}$ & 281 & n.a. \\
\hline $\mathbf{W}$ & $<0.25$ & 0.88 \\
\hline $\mathbf{Y}$ & 6.27 & 2.74 \\
\hline $\mathbf{Y b}$ & 0.45 & 0.28 \\
\hline $\mathbf{Z n}$ & 54.6 & 71.0 \\
\hline $\mathbf{Z r}$ & 10.3 & 11.3 \\
\hline As & n.a. & 17.5 \\
\hline $\mathbf{B i}$ & $<0.25$ & $<0.625$ \\
\hline Hg & n.a. & 0.012 \\
\hline Sb & 0.412 & 13.5 \\
\hline Se & n.a. & 2.38 \\
\hline Au & n.a. & $<0.002$ \\
\hline${ }_{-} \mathrm{H}_{2} \mathrm{O}$ & 0.85 & n.a. \\
\hline$+\mathrm{H}_{2} \mathrm{O}$ & 3.04 & n.a. \\
\hline $\mathrm{CO}_{2}$ & 11.1 & n.a. \\
\hline
\end{tabular}

FRIED, 2007, PIRAJNO, 2009, BODNAR et al., 2014 and references therein) can not be applied to their hydrothermal systems.

The Triassic and Jurassic basalts studied here were affected by hydrothermal alteration on slightly different scales. Hydrothermal alteration minerals are more abundant in the Triassic than the Jurassic localities, but all occurrences can be categorised into three main groups, according to the model of HART (1973); (1) primary hydrothermal alteration, (2) cooling related hydrothermal alteration and (3) low-temperature hydrothermal alteration. This classification is followed in the discussion below. Using this scheme for evaluation of all the available data, the characteristics of the single processes and the importance of the medium (i.e. seawater or unconsolidated sediment) can also be determined.

\section{Primary hydrothermal alteration}

Primary alteration is present at each studied locality, represented by albititisation of rock forming plagioclase. This took place im- 

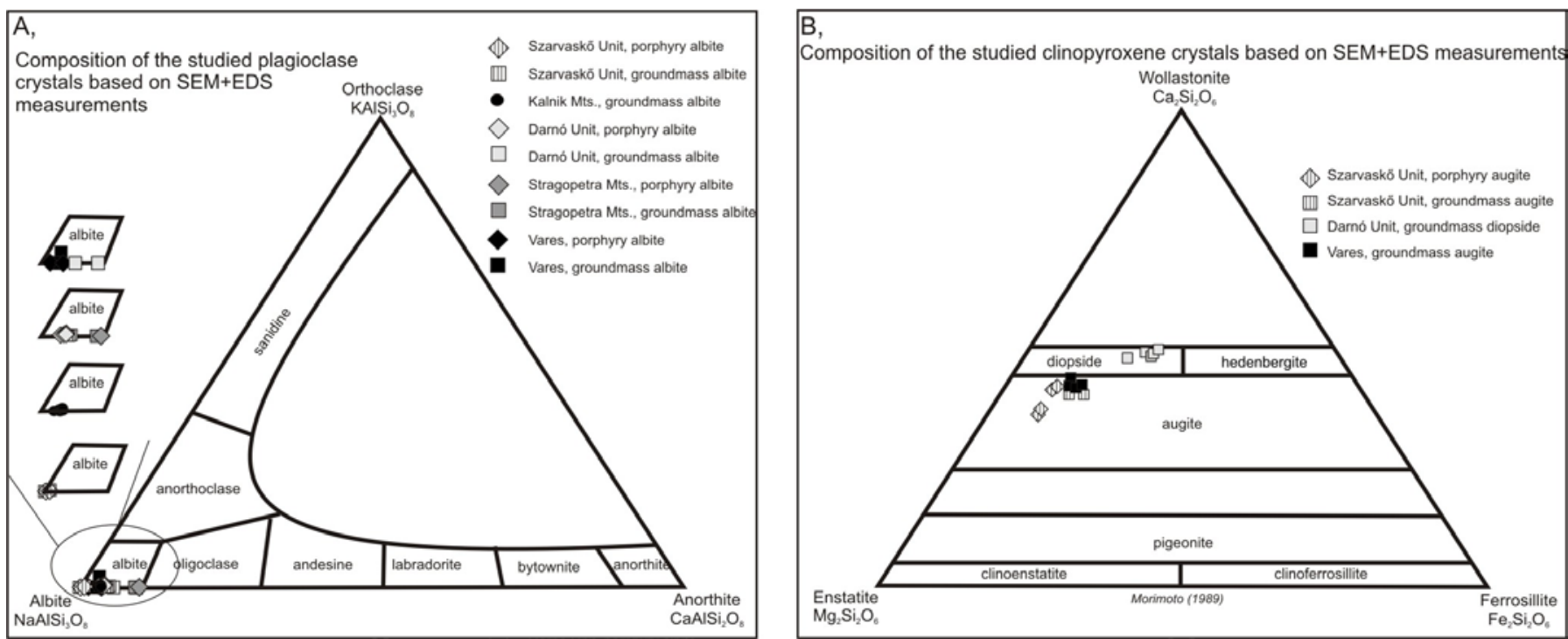

Figure 3. Classification diagrams based on the results of the SEM-EDS analyses. The composition of the studied plagioclase (A) and pyroxene (B) grains are shown.

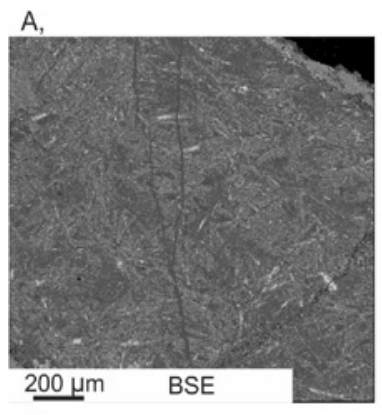

$\mathrm{D}$,

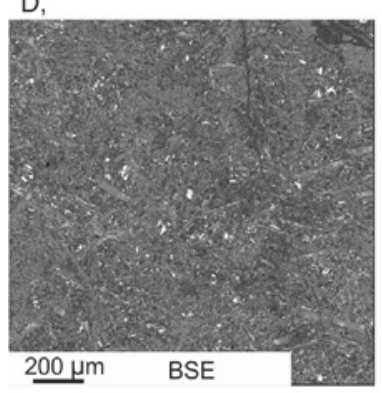

G,

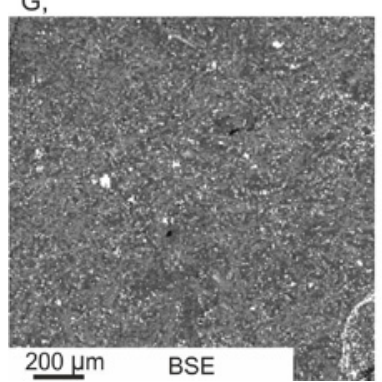

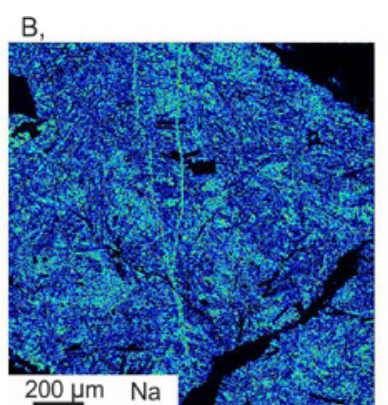

E,
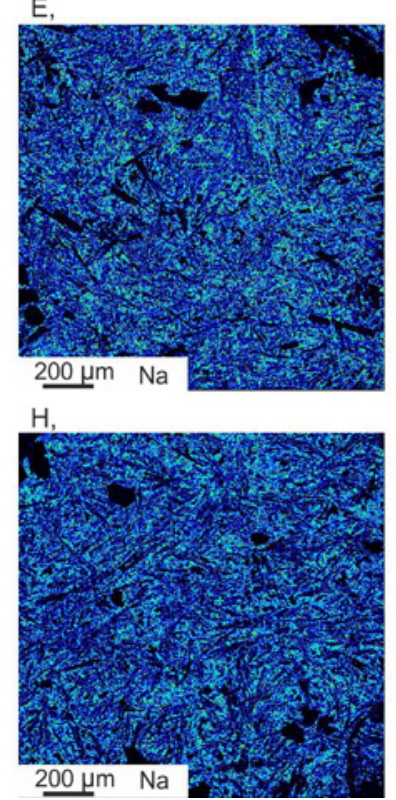

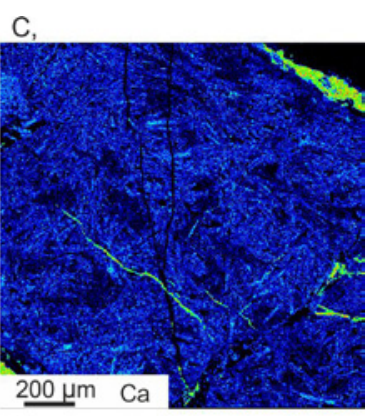

$\mathrm{F}$,
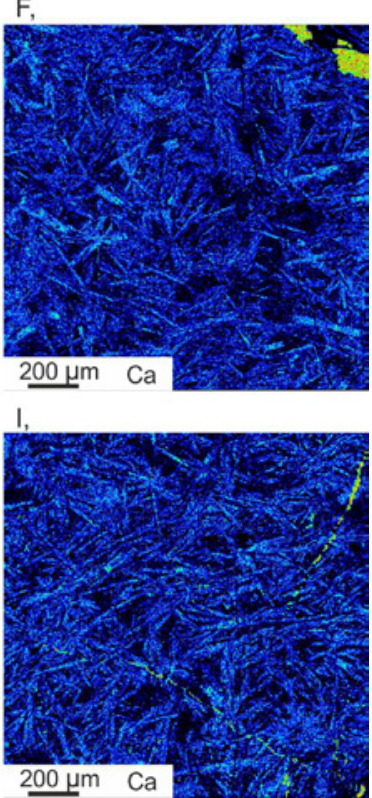

Figure 4. Results of the EPMA elemental mapping in a single thin section. Plagioclase laths contain more $\mathrm{Na}$ and less $\mathrm{Ca}$ at the margin of the pillows (A-C), than ca. $1.5 \mathrm{~cm}$ closer to the middle (D-F) and ca. $3 \mathrm{~cm}$ closer to the middle (G-I). The section is from a Triassic basalt (RM-131 drillcore, Darnó Unit, Hungary).

mediately after solidification of the submarine basaltic flows, as albitisation characterises both the groundmass plagioclase and the porphyric plagioclase. This process could occur around $300^{\circ} \mathrm{C}$, according to HART (1973).

\section{Cooling related hydrothermal alteration}

The textural characteristics of the basalt (sphaerolitic, variolitic or intersertal texture; skeletal crystal plagioclase, high amount of glassy/microcrystalline material) as well as the composition of the clinopyroxene (high $\mathrm{Ca}, \mathrm{Al}$ and Fe content, NISBET \& PEARCE, 1977) suggest a very rapid cooling of the basaltic lava. This together with the known geotectonic position (i.e. the absence of a deep-seated long-lasting heatsource), have obvious effects on the possibilities of the fluid/ rock interaction. Thus, only very rapid, cooling related hydrothermal processes took place and protracted fluid convection 

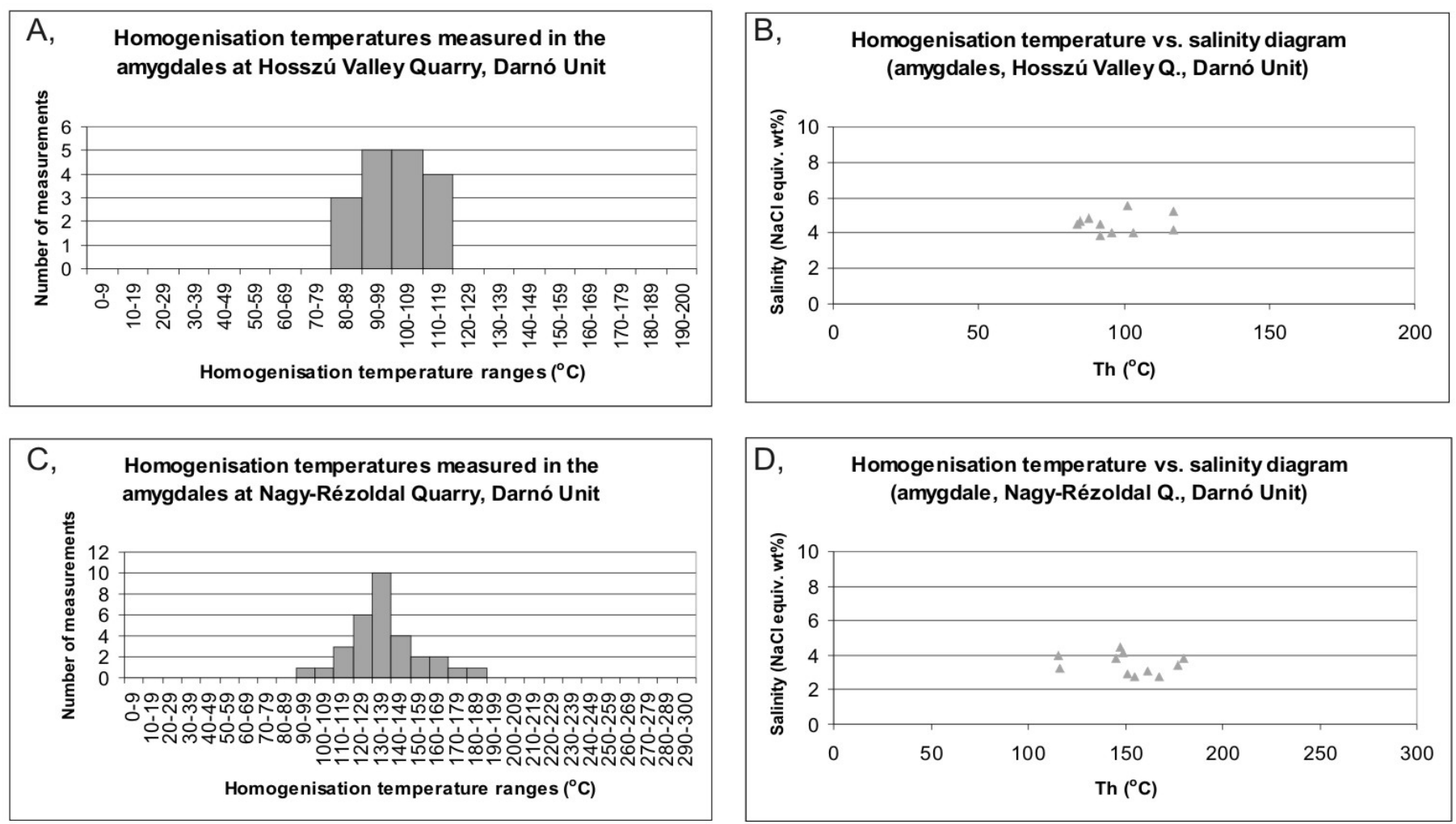

Figure 5. Results of the fluid inclusion study obtained from Triassic amygdale filling calcite.
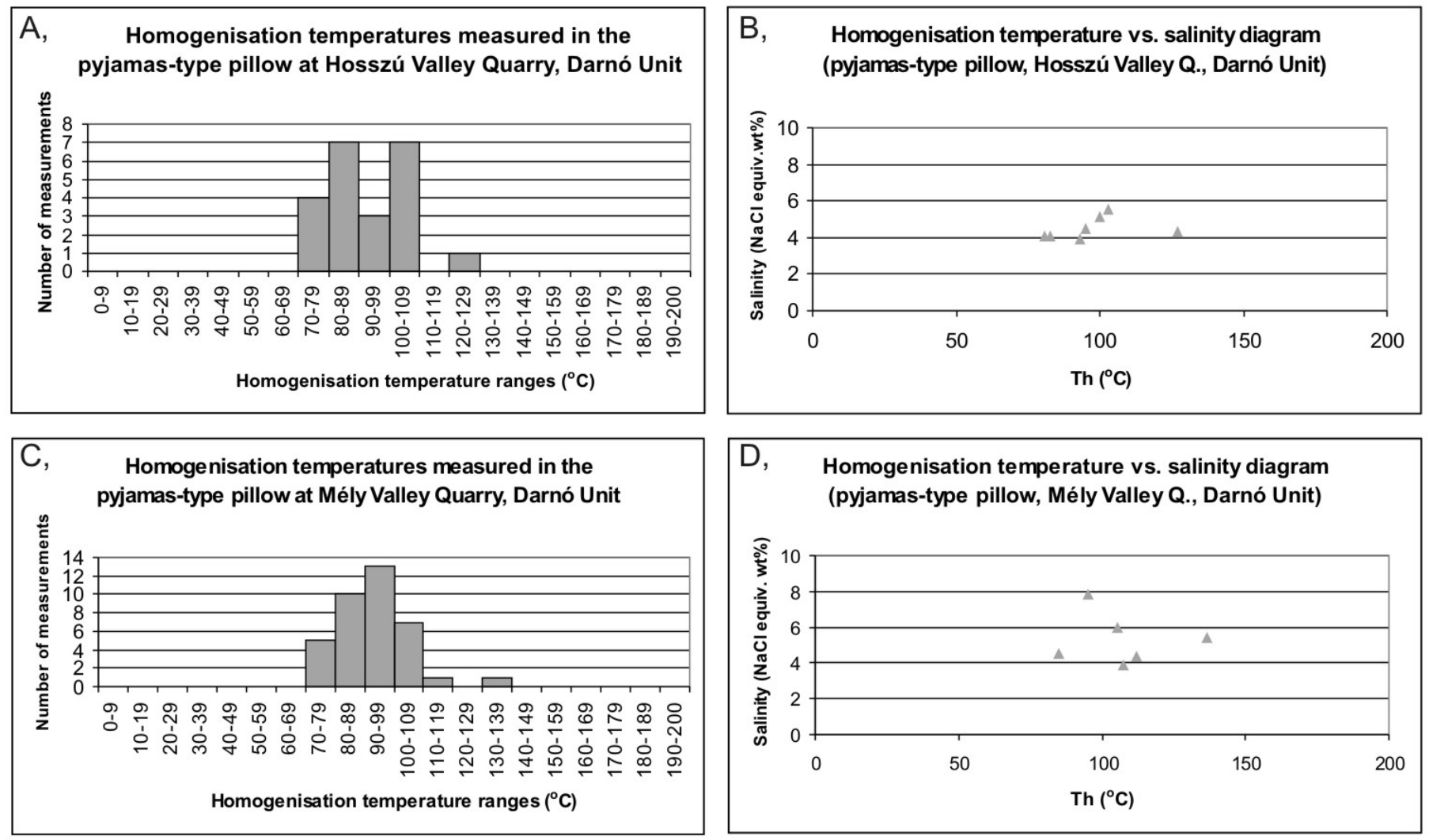

Figure 6. Results of the fluid inclusion study obtained from the calcite of the mineral bands of Triassic pyjamas-type pillow.

did not develop. However, some difference between the Triassic and the Jurassic localities can be observed, as signs of rapid cooling are less dominant in the Jurassic basalts (intersertal textures with smaller amounts of microcrystalline material are more common).
Chloritisation of the ground mass and the formation of the different hydrothermal mineral infillings (cooling cracks, amygdales, mineral band of the pyjamas-type pillow, matrix of the hyaloclastite breccia) have taken place during this cooling related alteration. Although the mineral paragenesis may be similar to that 

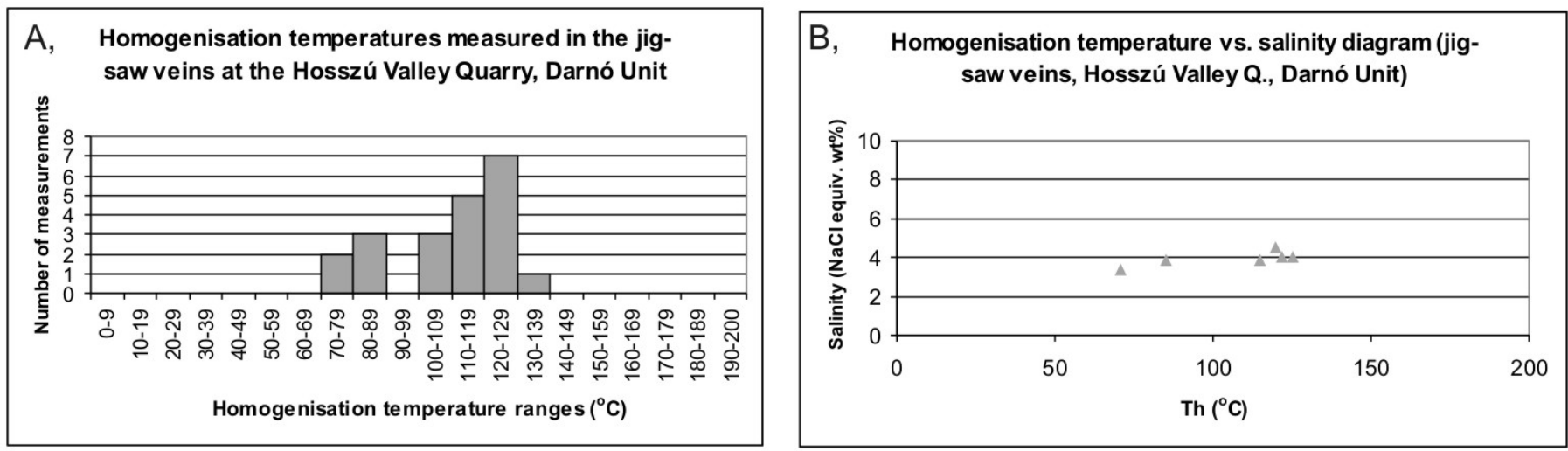

Figure 7.: Results of the fluid inclusion study obtained from Triassic jig-saw vein filling calcite.
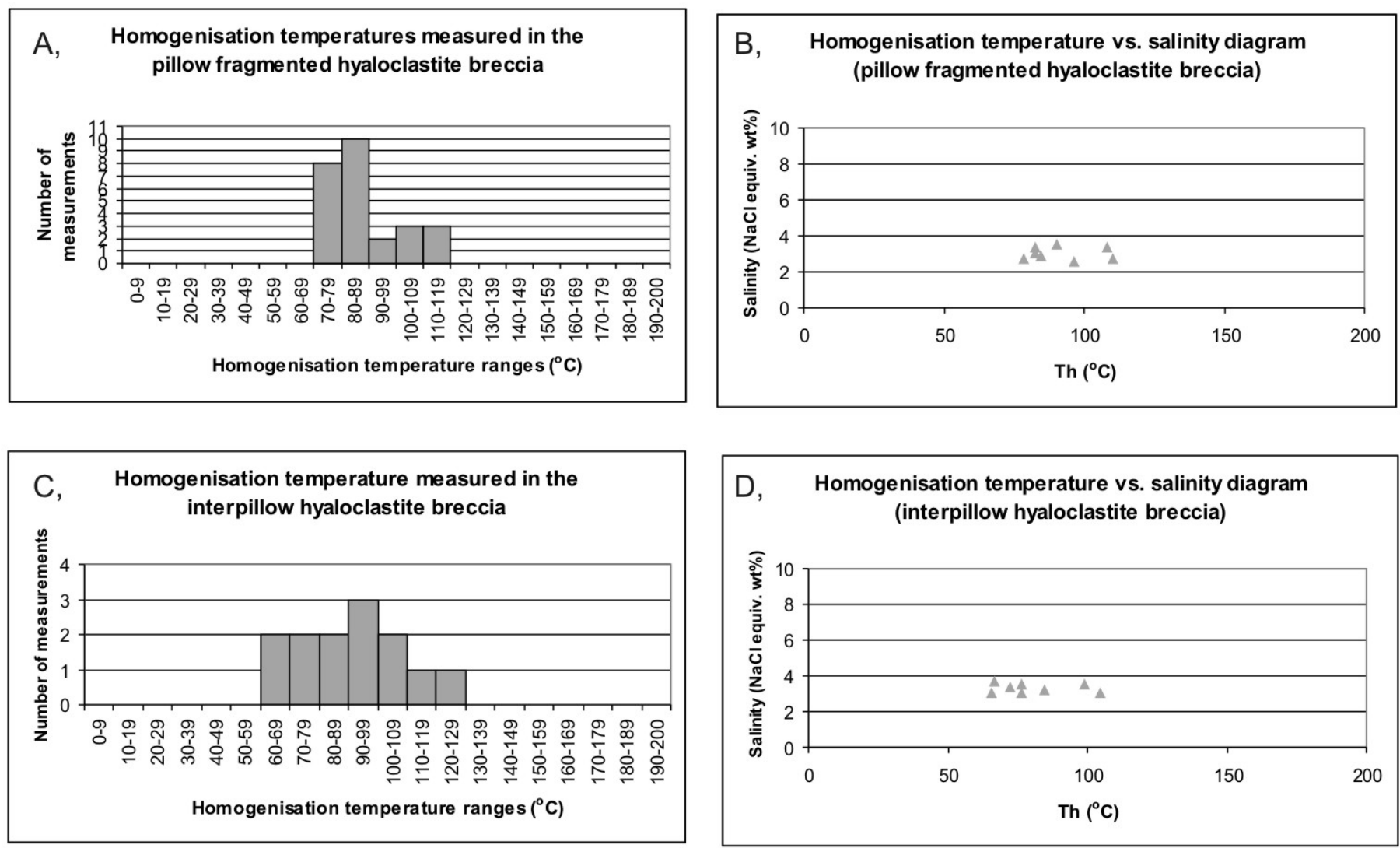

Figure 8. Results of the fluid inclusion study obtained from the calcite of the matrix of Triassic hyaloclastite breccias.

usually connected to low-grade Alpine metamorphism, the obvious textural features (e.g. the cooling cracks do not cross-cut the pillow boundaries) and also the observed fluid characteristics ( $T$, $\mathrm{X}$, see e.g. in KISS et al., 2011) help to distinguish different steps of the submarine hydrothermal process from the later low-grade metamorphic overprint (Figs. 11-15). However, the cooling-related mineral paragenesis is slightly different in the Triassic and Jurassic basalts at the studied localities. The Triassic basalts are generally characterised by chlorite with some quartz and prehnite in the early high temperature alteration stage, and abundant calcite, together with rare epidote, prehnite, zeolite and pumpellyte formation at the lowest temperatures. In contrast, the Jurassic localities are abundant in the high temperature products of chlorite, quartz and prehnite, and only a low amount of lower temperature calcite and pumpellyite occur (Figs. 11-15).
On the basis of chlorite thermometry (Table 5), chloritisation of the ground mass, pseudomorph formation after olivine, as well as formation of some thin, cooling related veinlets, took place at around $180-280^{\circ} \mathrm{C}$. This kind of chlorite is associated with some calcite, quartz, prehnite, pumpellyite and epidote, and their formation was the earliest step of the cooling-related processes.

Infilling of the smaller and larger amygdales in the Triassic basalts and some thin veins in both basalts, together with the onset of mineral precipitation in the matrix of the interpillow and pillow fragmented hyaloclastite breccia, collectively represent the next step of the cooling-related fluid/rock interactions. Temperatures around $200^{\circ} \mathrm{C}$ are characteristic for the small, chlorite or chloritequartz filled amygdales, for precipitation of chlorite along the walls of larger amygdales and in thin veins, as well as for the 

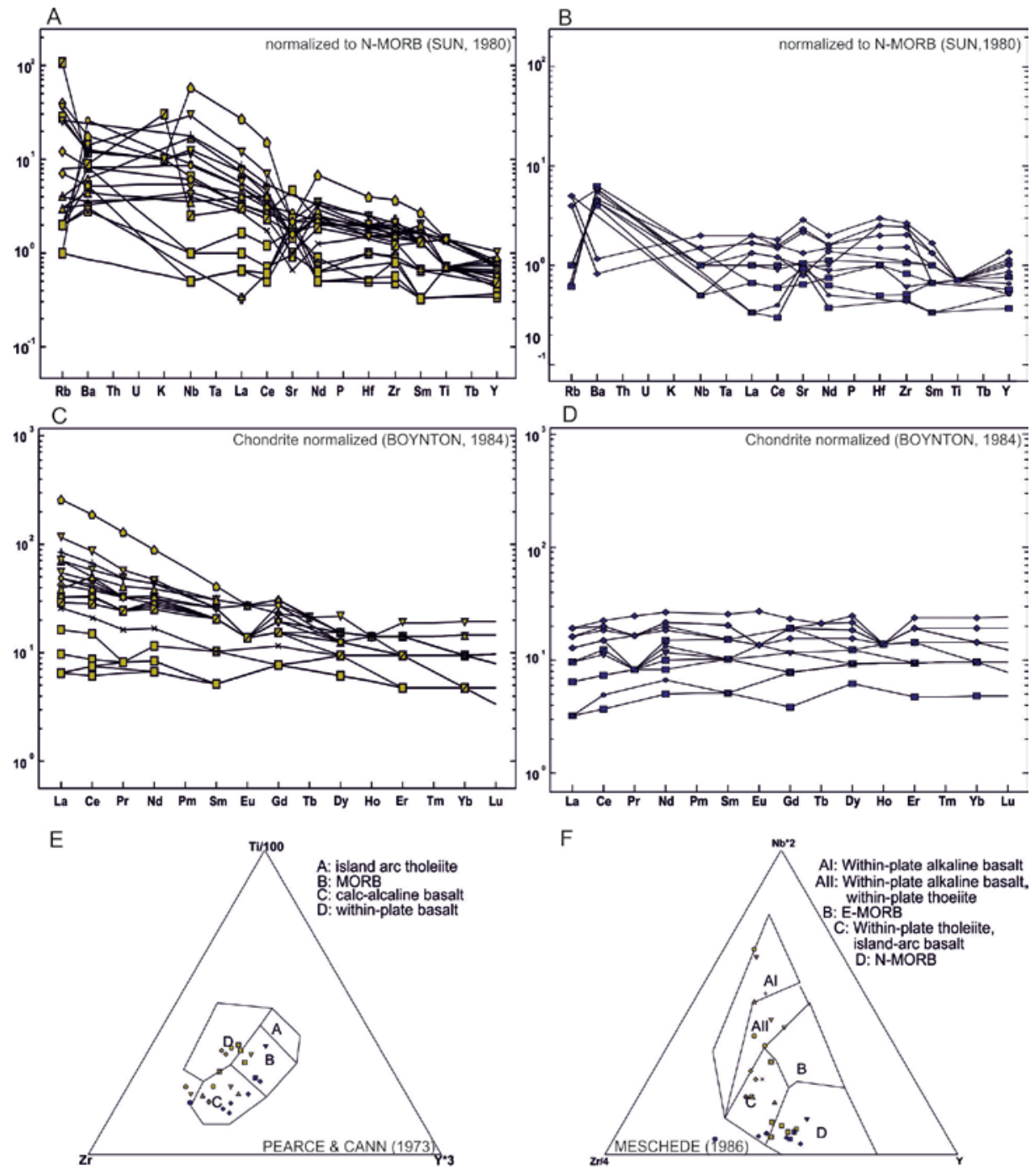

$\mathrm{F}$

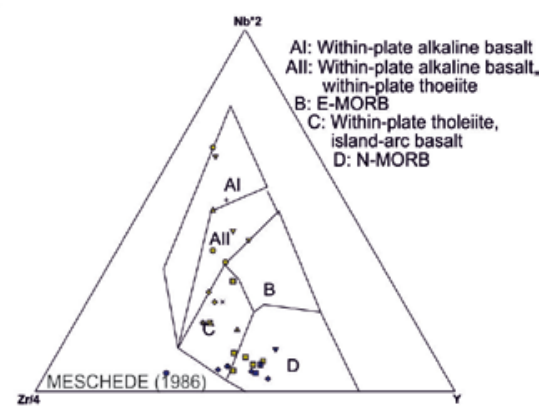

Figure 9. Results of the geochemical analyses. A, B: N-MORB normalised trace element spider diagram of the Triassic (A) and Jurassic (B) basalts. C, D: Chondrite normalised REE spider diagram of the Triassic (C) and Jurassic (D) basalts, note the clear difference observable between them. E: Discrimination diagram of PEARCE \& CANN (1973), showing different fields of origin for the Triassic and Jurassic localities. F: Discrimination diagram of MESCHEDE (1986), showing different fields of origin for Triassic (mostly withinplate basalt) and Jurassic (mostly islandarc and N-MORB) localities. earliest precipitation of chlorite grains in the matrix of hyaloclastite breccias (Table 5).

The fluid inclusion study revealed that the homogenisation temperatures and salinity values are similar to those from the calcite-filled amygdales, pyjama-type pillows and jig-saw veins of some other Darnó Hill locations, and others at Vareš and the Stragopetra Mts. (KISS et al., 2012). Combining all the data presented in KISS et al. (2012) and here (Figs. 5-8, Table 4), suggests that the lowest temperature stages of the cooling-related fluid/rock interactions can be related to precipitation of calcite in the amygdales, jig-saw veins, former feeding channels, mineral bands of the pyjama-type pillows and in the cement of the hyaloclastite breccia. As the homogenisation temperature corresponds to the minimum formation temperature in the case of the homogenous state of the parent fluid, the exact formation temperatures can be calculated if the pressure conditions of the entrapment of the in- clusions are known. In these submarine systems, the pressure is determined by the depth of the seawater. For the Triassic localities, $1.5 \mathrm{~km}$ water depth is proven at Vareš-Smreka from a combination of chlorite thermometry and fluid inclusion data (KISS et al., 2012), while a maximum of $4 \mathrm{~km}$ depth is assumed for the Darnó area (BALLA et al., 1980). Those pressures result in around $10-20{ }^{\circ} \mathrm{C}$ correction of the homogenisation temperatures. However, in the case of the Jurassic localities, deeper water ( 4-6 km) is indicated by the combination of chlorite thermometry with fluid inclusion data (KISS et al., 2011), resulting in a $20-28{ }^{\circ} \mathrm{C}$ correction of the homogenisation temperature data. Applying this correction to the Triassic basalts, the highest temperature conditions for precipitation of calcite existed in the amygdales $(\sim 100-180$ ${ }^{\circ} \mathrm{C}$ ), whereas the lowest temperature conditions characterised the jig-saw veins $\left(\sim 70-140^{\circ} \mathrm{C}\right)$ and the feeding channel and pyjamatype pillow infillings as well as from the hyaloclastite breccia matrix $\left(\sim 80-150{ }^{\circ} \mathrm{C}\right)$ (Figs. 11-14). The rather wide range (together 

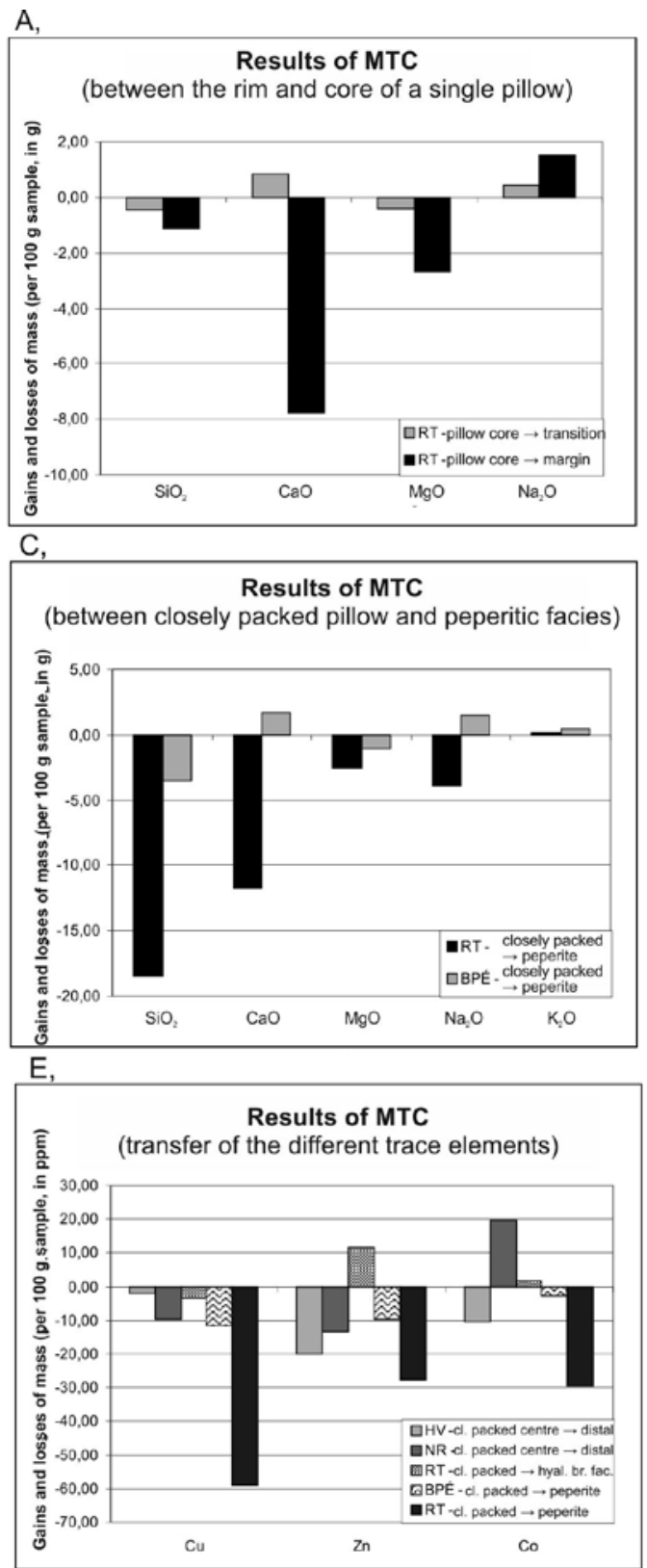

$\mathrm{B}$,
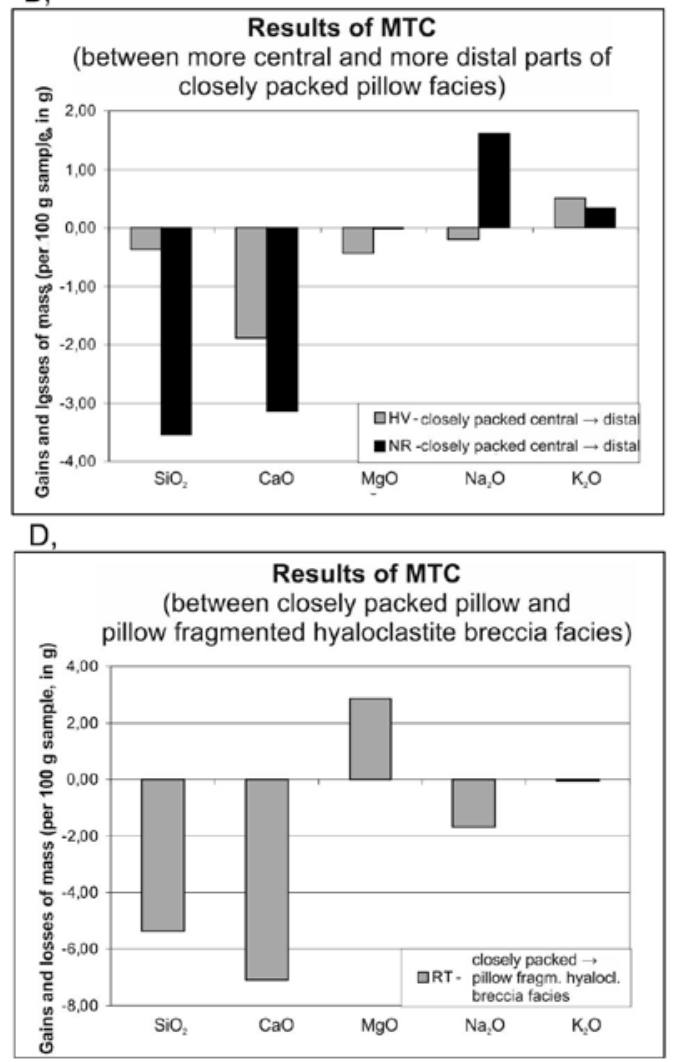

Figure 10. Results of the mass transfer calculations. Gains and losses of mass of major elements within a single pillow, from core to rim (A), from more central to more distal parts of the same closely packed pillow facies (B), between the closely packed and peperitic pillow facies (C), between the closely packed pillow ad pillow fragmented hyaloclastite breccia facies (D) and gains and losses of mass of trace elements (E). Abbreviations: BPÉ: Báj-patak Quarry, RT: Reszél-tető Quarry, HV: Hosszú Valley Quarry, NR: Nagy-Rézoldal Quarry, cl. packed: closely packed pillow facies, hyal. br. fac.: pillow fragmented hyaloclastite breccia facies. with the significantly lower temperature, in relation to the chlorite formation temperatures) can result from very rapid cooling, i.e. a significant difference can be observed from the margin to the centre of a single amygdale or vein. In contrast, the formation temperature range of the cooling crack calcite in the Jurassic basalt is narrower at approx. $130-170{ }^{\circ} \mathrm{C}$ (KISS et al., 2011).

Another important characteristic parameter of the processes is the salinity of the parent fluid (see Figs. 5-8 and Table 4). For the Triassic samples, the fluid inclusion salinities were 3.3-5.6 NaCl equiv. wt $\%$, which is around, and just a bit higher, than seawater salinity. The slightly higher salinities may be caused by the effect of the fluid-rock interactions on the composition of upheated seawater (NEHLIG, 1991). This process is a good explanation for the salinity increase in the thin veins, or amygdales (especially along their walls), where the effective local water/rock ratio is lower. However, it also explains the fact that in the case of the different hyaloclastite breccias (where the local water/rock ratio is obviously higher), the salinity is always similar to the seawater value (Fig. 16). In contrast, the results of the thin cooling cracks found in the Jurassic basalts correspond to 4.95-9.07 $\mathrm{NaCl}$ equiv. wt $\%$ (KISS et al., 2011), thus a lower water/rock ratio is expected (NEHLIG, 1991), which may explain (together with the observed higher formation temperatures) the slightly different mineral paragenesis.

The results of our studies can be compared with the characteristics of the hydrothermal system at Hruškovec, where a complete submarine volcanic lava flow is known (see above, PALINKA $\breve{S}$ et al., 2008). There, a maximum of $150^{\circ} \mathrm{C}$ as homogenisation temperature and seawater salinity is characteristic of the relatively distal facies in relation to the eruptive centre, while up to $250{ }^{\circ} \mathrm{C}$ homogenisation temperature, boiling of fluids and up to $23 \mathrm{NaCl}$ equiv. wt $\%$ salinities (which may be caused by boiling of the modified seawater, see e.g. PIRAJNO, 2009 and BODNAR et al., 2014) are typical in the central zones of the lava flow (BOROJEVIĆ et al., 2000, Borojević pers. comm.). Therefore, the fluid inclusion data fully supports the results of the volcanic facies analysis of KISS et al. (2008, 2010, 2012), i.e. the presence of only distal facies at the presently studied, strongly tectonised localities. 


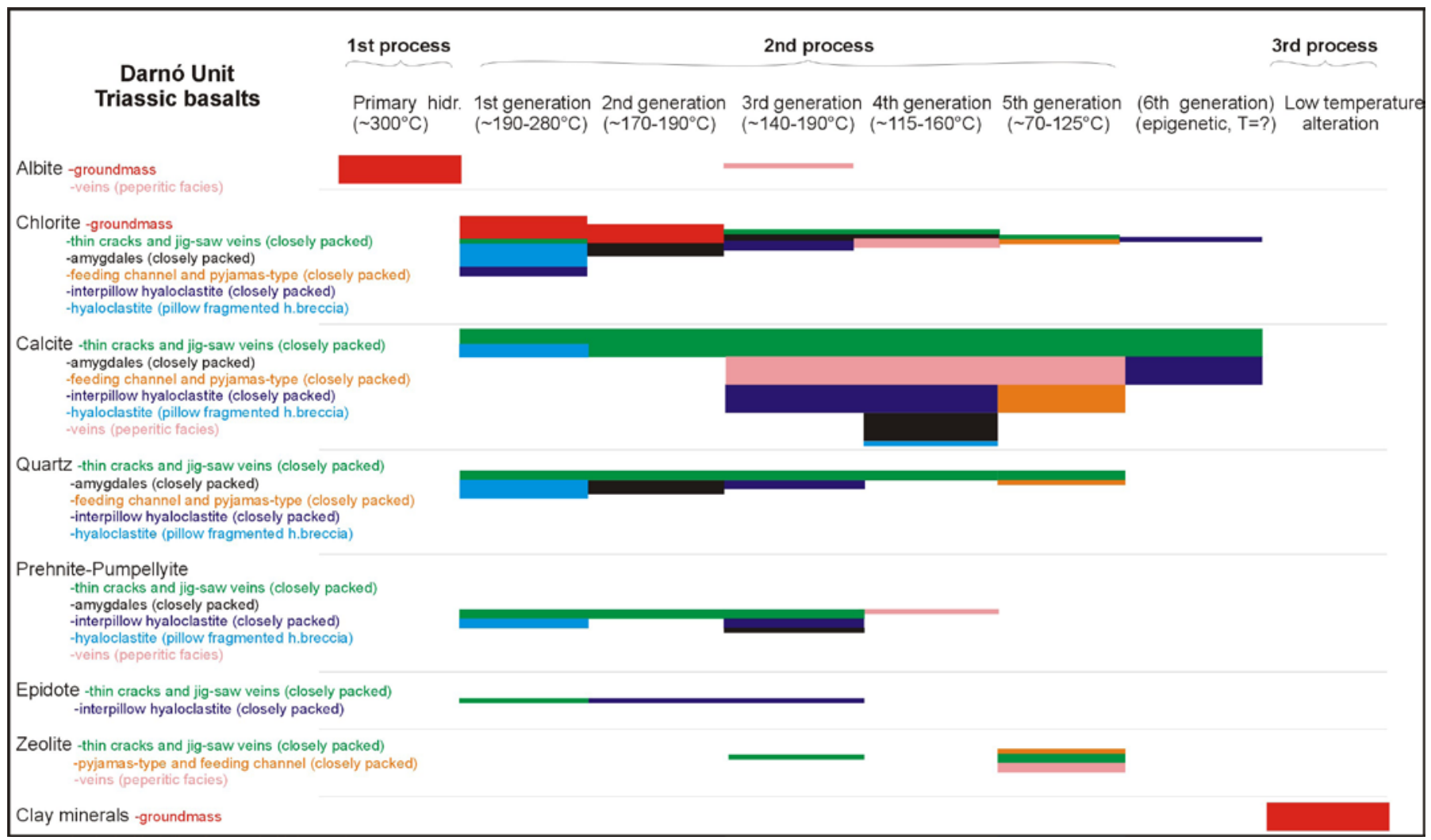

Figure 11. Mineral precipitation sequence according to the volcanic facies at the Darnó Unit, Hungary.

\section{Kalnik Mts. Triassic basalt}

1st process

Primary hidr. 1st generation 2nd generation (3rd generation) Low temperature $\left(\sim 300^{\circ} \mathrm{C}\right)$

\section{(20)}

Albite -ground mass

Chlorite -ground mass

-thin cracks andjig-saw veins (closely packed)

Epidote -thin cracks and jig-saw veins (closely packed) -veins (peperitic facies)

Calcite -thin cracks and jig-saw veins (closely packed) -veins (peperitic facies)

-amygdales (closely packed)

-pyjamas-type and feeding channel (closely packed)

Prehnite -thin cracks and jig-saw veins (closely packed) -pyjamas-type and feeding channel (closely packed) -veins (peperitic facies)

Clay minerals -ground mass

\section{2nd process}

\section{3rd process}

$\left(\sim 190-280^{\circ} \mathrm{C}\right) \quad\left(\sim 115-190^{\circ} \mathrm{C}\right)$ epigenetic, $\left.\mathrm{T}=?\right) \quad$ alteration

Figure 12. Mineral precipitation sequence according to the volcanic facies at the Kalnik Mts., Croatia.

\section{The low temperature hydrothermal alteration}

The low temperature hydrothermal alteration in the submarine basaltic mounds is the result of the long-lasting seawater-rock interaction at temperatures below $70{ }^{\circ} \mathrm{C}$. According to HART (1973), formation of K-rich smectites is characteristic of this low temperature process. Studies by PICHLER et al. (1999), ALT \& TEAGLE (2003) and SCHRAMM et al. (2005) also confirmed this together with occurrences of celadonite, saponite, iron oxy-hydroxides and rarely, illite-smectite and chloritesmectite interlayered clay minerals.
Iron oxy-hydroxides occur at all localities studied, but it cannot be stated clearly, whether their occurrence is part of this low temperature alteration process, or to later processes (e.g. to weathering). However, the presence of abundant phyllosilicates can be related to this low temperature hydrothermal process as chlorite-smectite interlayered clay minerals occur both in the groundmass and in some amygdales of basalt. As well as the presence of chlorite-illite interlayered clay minerals, celadonite and smectite were also detected in the basalt at all the studied localities. 


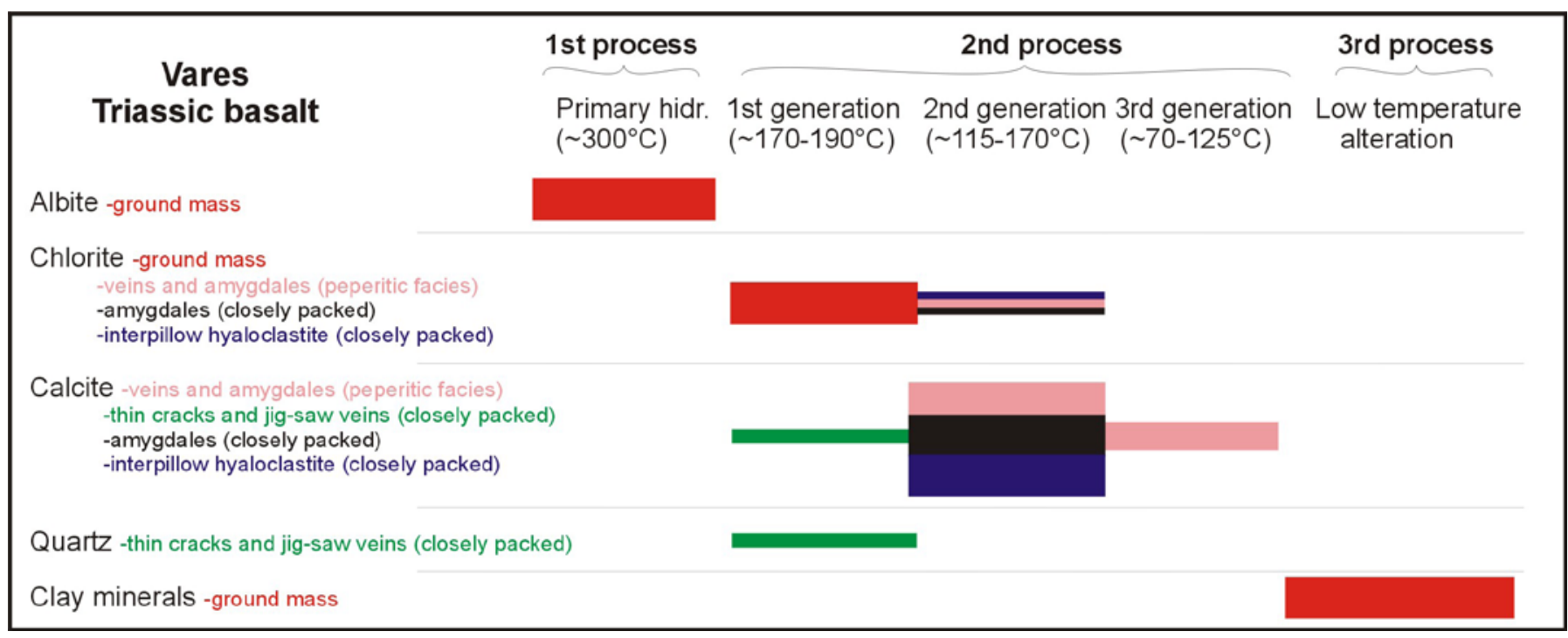

Figure 13. Mineral precipitation sequence according to the volcanic facies at Vareš, Bosnia and Herzegovina.

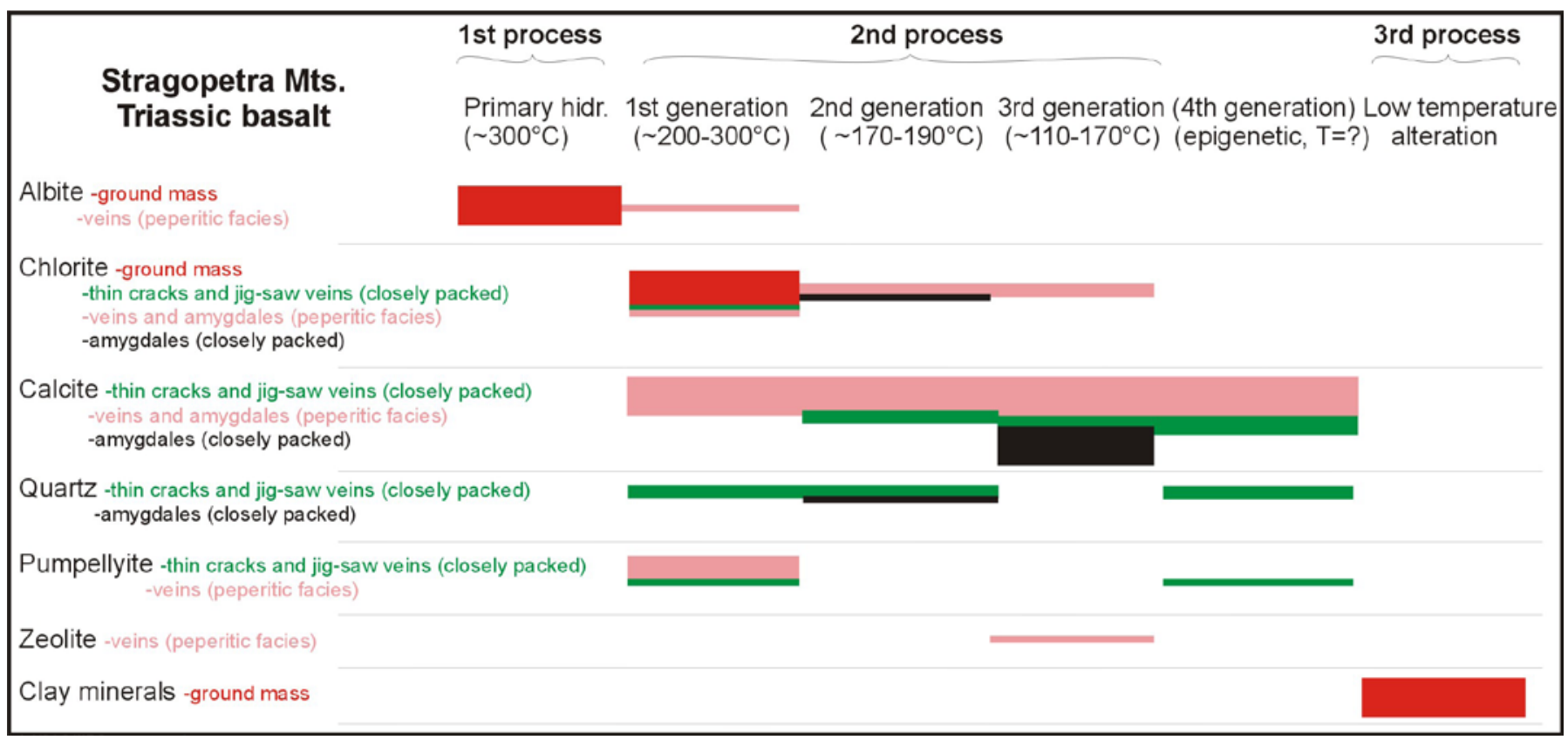

Figure 14. Mineral precipitation sequence according to the volcanic facies at Stragopetra Mts., Greece.

\section{Geochemical features of fluid/rock interaction}

As shown in the previous studies, the major and trace element characteristics of basaltic rocks from the studied localities support a different origin for the Triassic and Jurassic basalts; i.e. a rifting related (within-plate basalt) origin for the Triassic examples (KISS et al., 2012) and a subduction related origin for the Jurassic basalts (KISS et al., 2011). However, submarine hydrothermal processes certainly have strong effects on the geochemical composition of these rocks (see e.g. HART, 1973, WILSON, 1989, KARAMATA et al., 2000, etc), especially if the basalt interacted not only with the seawater, but also with the unconsolidated sediment. The latter may have significant effects also, though it has not been previously studied in detail (see e.g. MUKHERJI, 1972). Therefore the significant scattering of results for a few elements (e.g. $\mathrm{Ca}, \mathrm{Mg}, \mathrm{Na}, \mathrm{K}, \mathrm{Fe}, \mathrm{Mn}, \mathrm{Au}, \mathrm{Cu}$, $\mathrm{Zn}, \mathrm{Pb}$, and LILE group, Fig. $9 \mathrm{~A}, \mathrm{~B}$ ) can be explained by the mobility of those elements during hydrothermal processes.

\section{Traces of component mobilisation}

Using the MTC method, component mobilisation during the submarine hydrothermal processes were quantitatively modelled. Although the number of available analyses does not allow generalised conclusions to be drawn, some preliminary interpretations can be made based on observed variations.

Slightly different mobilisation patterns were seen at different scales (Fig. 10 A-D). Within a single pillow, from the centre to its margin, or within the closely packed pillow facies from less to more distal parts, the amount of $\mathrm{CaO}$ decreases, while the amount of $\mathrm{Na}_{2} \mathrm{O}$ increases. Both show good correlation with the macroscopically and microscopically observed alteration intensity of the studied samples. A slight increase of $\mathrm{K}_{2} \mathrm{O}$ is detected only on larger scales, from less to more distal parts of a single facies or between less and more distal facies, in relation to the centre of the lava flow. 


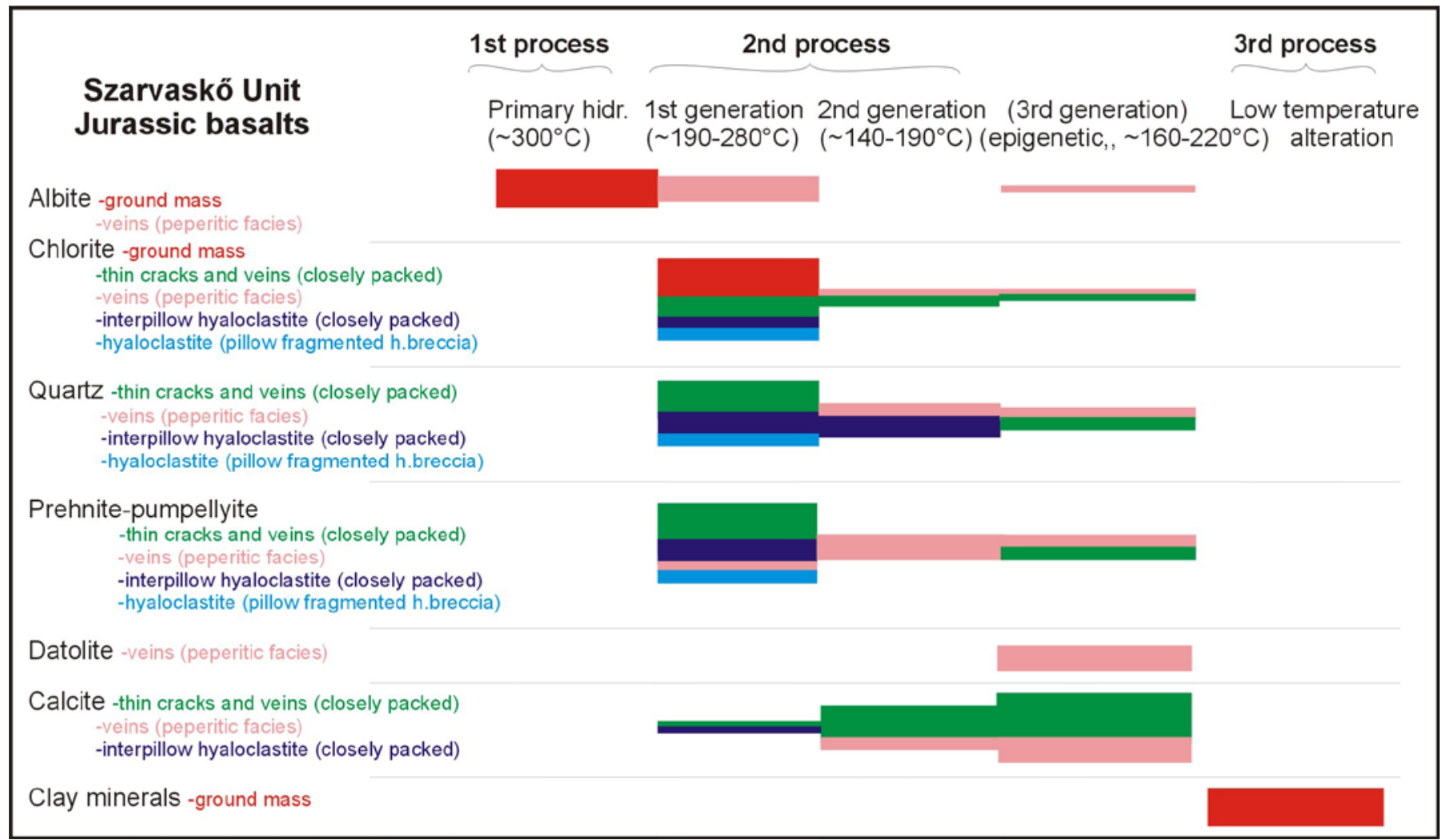

Figure 15. Mineral precipitation sequence according to the volcanic facies at the Szarvaskő Unit, Hungary.

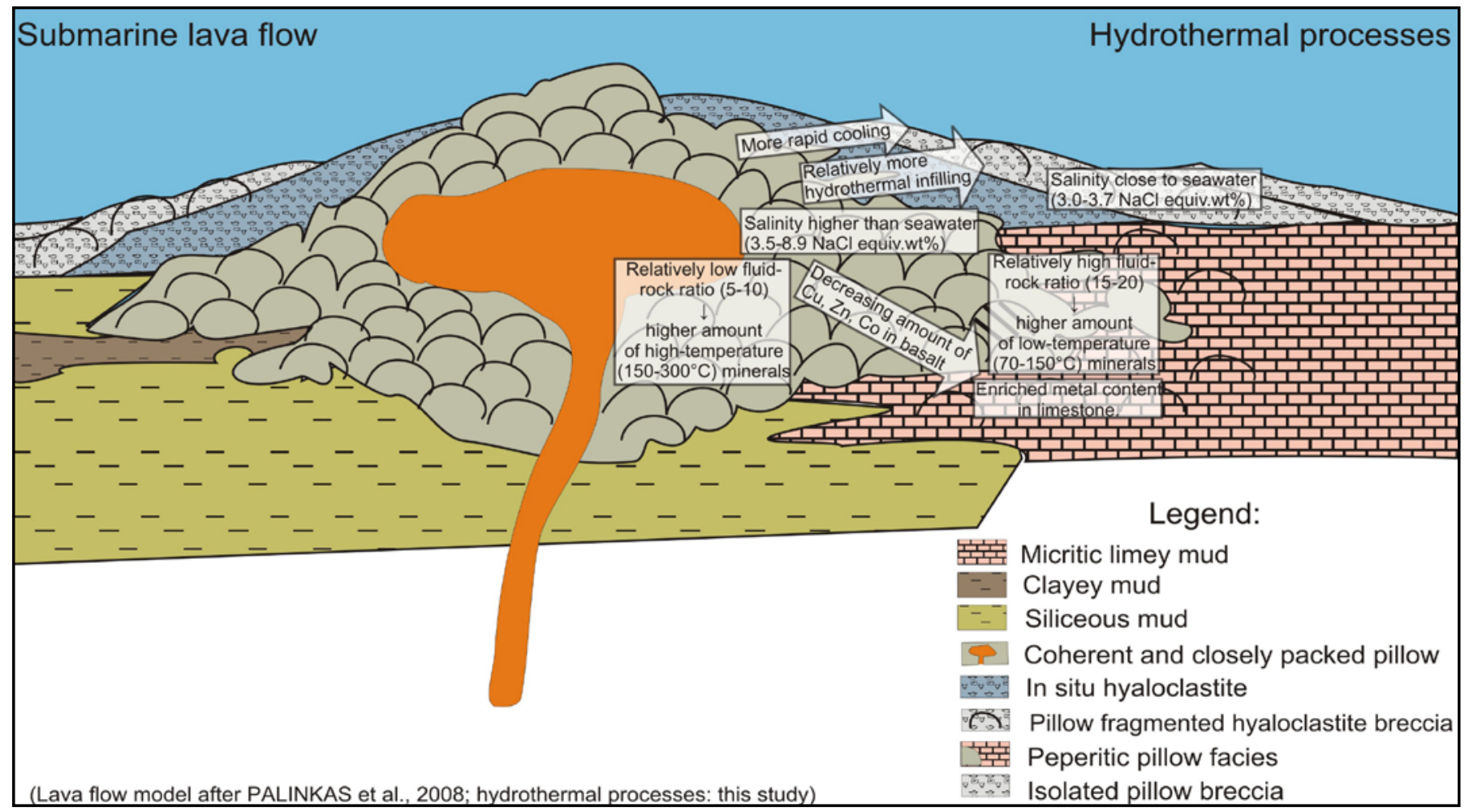

Figure 16. Schematic model of a submarine lava flow (PALINKAS̆ et al., 2008) and the results of the affecting hydrothermal processes.

However, a decrease of $\mathrm{SiO}_{2}$ was observed in all studied cases. These changes may be explained by the petrographically observed mineral paragenesis modifications, e.g. the albitisation of anorthite during primary hydrothermal alteration (change in $\mathrm{Na}_{2} \mathrm{O}$ and $\mathrm{CaO}$ content) or the formation of $\mathrm{K}$-rich clay minerals (change in $\mathrm{K}_{2} \mathrm{O}$ and $\mathrm{SiO}_{2}$ content) during low temperature alteration.

Important conclusions can be drawn regarding the metal content at the studied localities. Copper, zinc and cobalt commonly decrease, from the less distal (thus less altered) to the 


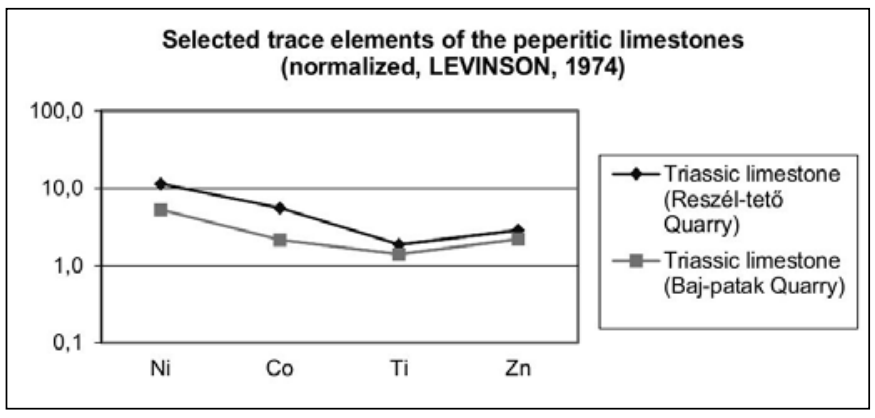

Figure 17. Selected trace element spider diagram of the studied peperitic limestones, showing enrichment in relation to typical limestones (LEVINSON, 1974).

more distal (thus more altered) parts of either a single pillow or the volcanic centre (Fig. $10 \mathrm{E}$ ).

Tracing the effects of the different steps of the hydrothermal processes was possible at several scales from a single pillow to an outcrop, raising the question of whether these phenomena are also present at microscopic (thin section) scale. The EPMA elemental mapping revealed, that at such a scale, the plagioclase crystals contain more $\mathrm{Na}$ and less $\mathrm{Ca}$ closer to the margins of the pillows (sphaerolitic-variolitic texture), than in their inner parts (variolitic-intersertal texture), thus the relative enrichment of $\mathrm{Na}$ and depletion of $\mathrm{Ca}$ in the more altered parts is obvious (Fig. 4).

\section{The geochemical effects of the interaction with the uncon-} solidated sediment

The slight differences in the hydrothermal mineral parageneses (i.e. higher amount of infilling hydrothermal minerals and also, more mineral species, see Figs. 11-15) draw attention to the observation of the effects of unconsolidated sediment on the elemental compositon of the basalt. Based on the preliminary MTC calculations, more intensive component mobilisation can be recognised in the peperitic facies compared to other facies (see the greater amounts of gains/losses of mass on Fig. $10 \mathrm{C}$ ). Hence the geochemical analyses support the earlier petrographical assumption, i.e. the presence of water saturated, unconsolidated sediment strengthens the effect of hydrothermal alteration in the basaltic rocks. However, it was found that the limestone in the peperitic facies is enriched in $\mathrm{Co}, \mathrm{Zn}$, $\mathrm{Ti}$ and $\mathrm{Ni}$, in relation to a typical limestone (Fig. 17, LEVINSON, 1974). Thus, where lime mud was present during the submarine hydrothermal processes, the metals escaping from the basalt did not (or not only) dissolve in the seawater, but were also captured in the sediment.

\section{Determination of the water/rock ratio}

Although at the submarine basaltic eruption centres 'unlimited' amounts of seawater is available for the fluid/rock interaction processes, obviously the amount of water taking part effectively in the hydrothermal processes is lower, mostly depending on the available interaction surface. The study of the mineral paragenesis, as well as results of the fluid inclusion study have drawn attention to the importance of this local water/rock ratio (see above). Using the numerical results of the MTC calculations and the method described by SHIKAZONO et al. (1995), this effective water/rock ratio can be approximated. The results of the calculations support the earlier interpretations; at the closely packed pillow facies of the studied Triassic localities a higher water/rock ratio (1520 ) occurred, while at the studied Jurassic localities a lower ratio was obtained (5-10). This fact also supports the conclusion, that this local, effective water/rock ratio is a determining factor in these kinds of submarine hydrothermal systems.

\section{The general peculiarities of the hydrothermal process}

The observed main phases of the fluid/rock interaction processes, as well as the general features of mineral precipitation and the chemical changes are rather similar at both Triassic and Jurassic localities. In both cases the development of a small scale, rapidly cooling, and slightly modified/evolved seawater dominated system can be reconstructed. This is different from the typically large scale fluid circulation systems of the mid-oceanic ridges (see e.g. NEHLIG, 1991, FOUSTOUKOS \& SEYFRIED, 2007, PIRAJNO, 2009, BODNAR et al., 2014 and references therein). In addition to the main peculiarities listed above, other evidence can also be collected, including the absence of high temperature fluids, differences in the fluid composition properties and the lack of sulfate and sulfide phases. The clear difference from the large scale submarine hydrothermal systems also seems to be obvious in other rifting related submarine basaltic-sedimentary successions e.g. the low temperature, seawater dominated hydrothermal processes in the Mecsek Mts., Southern Hungary (JÁGER et al., 2012).

The observed slight, but important differences in the studied small-scale hydrothermal systems are also obvious. However, these differences in the texture, hydrothermal alteration mineralogy and fluid properties can be connected to the different position of the studied blocks in relation to the centre of the lava flow (i.e. different volcanic facies), particularly and practically by the different local, effective water/rock ratio (Fig. 16). Therefore, we conclude, that the features of the hydrothermal processes are typical to the volcanic facies and vice versa the observed characteristics may help in the spatial reconstruction of the original lava flow.

The distinction between the volcanogenic massive sulfide deposit forming i.e. large scale, and the non-extended, i.e. small scale hydrothermal systems is also economically crucial, as the latter does not tend to contain significant ore deposits. The afore-mentioned characteristics may help in distinguishing these different types of ore-productive and barren hydrothermal processes.

\section{CONCLUSIONS}

Submarine hydrothermal alteration of Triassic, advanced rifting related pillow basalt at different localities from the Dinarides, as well as from displaced fragments of the Dinarides and the Hellenides were compared with the alteration of Jurassic, back-arc/marginal-basin opening related pillow basalt series. The study aimed to complete the earlier less detailed knowledge on the general characteristics of the non-extended, submarine basaltic complex related hydrothermal systems.

The study revealed that the most important determining factors of these small scale hydrothermal systems are the extremely rapid cooling of the hydrothermal fluid, the dominance 
of the slightly modified seawater as a hydrothermal fluid and the dependence on the local, effective water/rock ratio (i.e. distal/proximal position within the lava flow). The observed features are typical of the volcanic facies, thus may also help in the identification of the spatial relationships within a submarine lava flow. The overall characteristics of these local, submarine basaltic volcanic centre related hydrothermal systems are markedly distinct from the typical mid-oceanic ridge or back-arc-basin opening related, volcanogenic massive sulfide deposit forming large scale hydrothermal systems (see e.g. NEHLIG, 1991, FOUSTOUKOS \& SEYFRIED, 2007, PIRAJNO, 2009 and BODNAR et al., 2014 and references therein).

Three main phases of submarine hydrothermal processes were distinguished and characterised: the primary hydrothermal processes, which took place at around $300{ }^{\circ} \mathrm{C}$ and caused the albitisation of the plagioclase; the hydrothermal alteration processes, during cooling from $300{ }^{\circ} \mathrm{C}$ to $\sim 50-70{ }^{\circ} \mathrm{C}$, resulting in the formation of the groundmass chlorite and all the other vein, cavity and amygdale filling hydrothermal minerals; and the low temperature hydrothermal processes below $\sim 50-70{ }^{\circ} \mathrm{C}$, resulting in formation of argillic alteration and iron oxy-hydroxides. Based on detailed observation of the textural features and the use of different geothermometry methods, more steps can be distinguished within the cooling related phase of the fluid/rock interaction process. Firstly the groundmass alteration product chlorite and the infilling minerals of the thin veinlets formed, which were followed by precipitation of the small and later the bigger amygdale infilling minerals. Later still, the infillings of the former feeding channel, and the mineral banding of the pyjama-type pillows precipitated, which was followed by the formation and filling of the jig-saw veins. At the highest temperatures $\left(300-150{ }^{\circ} \mathrm{C}\right)$ mostly chlorite, quartz and prehnite formed, while calcite, laumontite and pumpellyite are more common at lower temperatures $\left(150-70{ }^{\circ} \mathrm{C}\right)$. Thus, at those localities, where the higher temperature phases were longer lasting (e.g. the studied Jurassic ones), minerals from the first group are dominant, while in the other localities, characterised by dominantly lower temperatures (e.g. the studied Triassic localities), minerals from the latter group are more typical.

Component mobilisation during the different major phases and smaller steps of the hydrothermal processes were also traced. Based on the EPMA elemental mapping and mass transfer calculations, the gains and losses of mass during the fluid/rock interaction were followed at different scales (from microscopic to outcrop scale). The water-saturated sediment of the peperitic facies has strengthened the alteration efficiency of the hydrothermal processes. During the progressive alteration, the amount of $\mathrm{Cu}, \mathrm{Zn}$ and Co decreased, thus these metals dissolved into the seawater, but in the peperitic facies, they were also captured in the limestone.

\section{Acknowledgment}

Federica ZACCARINI (University of Leoben, Austria), Peter JONES (Carleton University, Ottawa, Canada) and Zsolt BENDÖ (Eötvös Loránd University, Budapest, Hungary) are thanked for their assistance with the EPMA and SEM-EDS analyses. The University Centre for Applied Geosciences
(University of Leoben) is thanked for the access to the Eugen F. STUMPFL Electron Microprobe Laboratory. Todor SERAFIMOVSKI (University “Goce Delčev"-Štip, Macedonia) and an anonymous reviewer are thanked for their constructive comments, improving the original version of the manuscript.

This work was supported by the Hungarian-Croatian Science and Technology Agreement Project no. 07/CRO to F. MOLNÁR and L. A. PALINKAŠ, by the OTKA (HNSF) research grant no. T 49633 to F. MOLNÁR and by the AÖU research grant no. 85 öu11 to G. B. KISS and F. ZACCARINI.

\section{REFERENCES}

AIGNER-TORRES, M. \& KOLLER, F. (1999): Nature of the magma source of the Szarvaskö complex (NE-Hungary).- Ofioliti, 24, 1-12.

ALT, J.C. \& TEAGLE, D.A.H. (2003): Hydrothermal alteration of upper oceanic crust formed at a fast-spreading ridge: mineral, chemical, and isotopic evidence from ODP Site 801.- Chem. Geol., 201, 191-211.

ÁRKAI, P (1983): Very low- and low-grade Alpine regional metamorphism of the Paleozoic and Mesozoic formations of the Bükkium, NE Hungary.-Acta Geol. Hung., 26, 83-101.

ÁRKAI, P (2001): Alpine regional metamorphism in the main tectonic units of Hungary: a review.-Acta Geol. Hung., 44/2-3, 329-344.

ÁRKAI, P., BALOGH, K. \& DUNKL, I. (1995): Timing of low-temperature metamorphism and cooling of the Paleozoic and Mesozoic formations of the Bükkium, innermost western Carpathians, Hungary.- Geologische Rundschau, 84/2, 334-344.

ÁRVÁNÉ SÓS E., BALOGH K., RAVASZNÉ BARANYAI L. \& RAVASZ CS. (1987): Mezozoós magmás kőzetek K/Ar kora Magyarország egyes területein (K/Ar age of mesozoic magmatic rock sin Hungary).- MÁFI Évi Jelentése az 1985. évről, 295-307 (in Hungarian).

BALLA, Z. (1984): The North Hungarian Mesozoic mafics and ultramafics.Acta Geol. Hung., 27, 341-357.

BALLA, Z. (1987): A Bükk-hegység mezozoós tektonikája és kapcsolata a Nyugati-Kárpátokkal és a Dinaridákkal (Tectonics of the Bükkian (North Hungary) Mesozoic and relations to the West Carpathians and Dinarides).- Alt. Földt. Sz., 22, 13-54 (in Hungarian).

BALLA, Z., BAKSA, CS., FÖLDESSY, J., HAVAS, L. \& SZABÓ, I. (1980): The tectonic setting of the ophiolites in the Bükk mountains (North Hungary).- Geol. Carpath., 31/4, 465-493.

BALOGH, K. \& PÉCSKAY, Z. (2001): K/Ar and Ar/Ar geochronological studies in the Pannonian-Carpathians-Dinarides (PANCARDI) region.-Acta Geol. Hung., 44, 281-299.

BODNAR, R.J., LECUMBERRI-SANCHEZ, P., MONCADA, D. \& STEELEMACINNIS M. (2014): Fluid Inclusions in Hydrothermal Ore Deposits.- In: HOLLAND, H.D. \& TUREKIAN, K.K. (eds.): Treatise on Geochemistry, Second Edition, Oxford: Elsevier, 13, 119-142.

BOYNTON, W.V. (1984): Cosmochemistry of the rare earth elements: meteorite studies.- In: HENDERSON, P. (ed.): Rare Earth Element Geochemistry, Elsevier, Amsterdam, 63-114.

BOROJEVIĆ, S., PALINKA ̌̌, L.A. \& BERMANEC, V. (2000): Fluid inclusions in Pillow Lavas of Hruškovec, Mt. Kalnik.- Proc. Croat. Geol. Congr., $123-125$.

BRAUHART, C.W., HUSTON, D.L., GROVES, D.I., MIKUCKI, E.J. \& GARDOLL, S.J. (2001): Geochemical mass transfer patterns as indicators of the architecture of a complete volcanic-hosted massive sulfide hydrothermal alteration system, Panorama District, Pilbara, Western Australia.-Econ. Geol., 96, 1263-1278.

BUDA, GY. \& KISS, J. (1980): Comparison some chromite and titaniferous magnetite, ilmenite ore bearing ultrabasic-basic complexes.- UNESCO Int. Symp. Athens, 1, 21-45.

CATHELINEAU, M. \& IZQUIERDO, G. (1988): Temperature - composition relationships of authigenic micaceous minerals in the Los Azufres geothermal system.-Contrib. to Mineral. Petrol., 100/4, 418-428.

CSONTOS, L. (1995): Tertiary tectonic evolution of the Intra-Carpathian area: A rewiev.-Acta Vulc., 7/2, 1-13.

CSONTOS, L. (1999): A Bükk-hegység szerkezetének főbb vonásai (Structure of the Bükk Mts.).-Földt. Közl., 129/4, 611-651 (in Hungarian).

CSONTOS, L. (2000): A Bükk hegység mezozoós rétegtani újraértékelése (Reevaluation of the mesozoic stratigraphy of the Bükk Mts.).- Földt. Közl., 130/1, 95-131 (in Hungarian).

CSONTOS, L. \& VÖRÖS, A. (2004): Mesozoic plate tectonic reconstruction of the Carpathian region.- Palaeogeogr., Palaeoclimat., Palaeoecol., 210, 1-56.

DIMITRIJEVIĆ, M. N., DIMITRIJEVIĆ, M. D., KARAMATA, S., SUDAR, M., GERZINA, N., KOVÁCS, S., DOSZTÁLY, L., GULÁCSI, Z., LESS, GY. \& PELIKÁN, P. (2003): Olistostrome/mélanges - an overview of the 
problems and preliminary comparison of such formations in Yugoslavia and NE Hungary.- Slovak. Geol. Mag., 9/1, 3-21.

DOSZTÁLY, L. \& JÓZSA, S. (1992): Geochronological evaluation of Mesosoic formations of Darnó Hill at Recsk on the basis of radiolarians and K-Ar age data.-Acta Geol. Hung., 35/4, 71-393.

DOSZTÁLY, L., GULÁCSI, Z. \& KOVÁCS, S. (1998): Az észak-magyarországi jura képződmények rétegtana (Stratigraphy of the N-Hungarian Jurassic rocks).- In: BÉRCZI, I. \& JÁMBOR. Á. (ed.): Magyarország geológiai képzödményeinek rétegtana, 309-318 (in Hungarian).

DOWNES, H., PANTÓ, GY., ÁRKAI, P. \& THIRLWALL, M.F. (1990): Petrology and geochemistry of Mesozoic igneous rocks, Bükk Mountains, Hungary.- Lithos, 24/3, 201-215.

FOUSTOUKOS, D.I. \& SEYFRIED, W.E. (2007): Fluid phase separation processes in submarine hydrothermal systems.- Reviews Mineral. Geochem., $65,213-239$.

GRANT, J.A. (1986): The isocon diagram - a simple solution to Gresens' equation for metasomatic alteration.- Econ. Geol., 81, 1976-1982.

HAAS, J. \& KOVÁCS, S. (2001): The Dinaric-Alpine connection - as seen from Hungary.- Acta Geol. Hung., 44/2-3, 345-362.

HAAS, J., KOVÁCS, S., PELIKÁN, P., KÖVÉR, SZ., GÖRÖG, Á., OZSVÁRT, P., JÓZSA, S. \& NÉMETH, N. (2011): A Neotethys-óceán akkréciós komplexumának maradványai Észak-Magyarországon (Remnants of the Neotethyan accretionary complexes in N-Hungary).- Földt. Közl., 141/2, 167196 (in Hungarian, with English abstract).

HALL, D.L., STERNER, S.M. \& BODNAR, R.J. (1988): Freezing point depression of NaCl-KCl-H O solutions.- Econ. Geol., 83, 197-202.

HARANGI, SZ., SZABỎ, CS., JÓZSA, S., SZOLDÁN, ZS., ÁRVA-SÓS, E., BALLA, M. \& KUBOVICS, I. (1996): Mesozoic igneous suites in Hungary: implications for genesis and tectonic settings in the Northwestern part of Tethys.- Int. Geol. Rev., 38, 336-360.

HART, R.A. (1973): A model for chemical exchange in the basalt-seawater system of oceanic layer II. - Can. J. Earth. Sci., 10, 799-816.

HRVATOVIĆ, H. (2006): Geological guidebook through Bosnia and Herzegovina.- Geological Survey of Federation Bosnia and Herzegovina, Sarajevo, $172 \mathrm{p}$.

JÁGER, V., MOLNÁR, F., BUCHS, D. \& KODERA, P. (2012): The connection between iron ore formations and "mud-shrimp" colonizations around sunken wood debris and hydrothermal sediments in a Lower Cretaceous continental rift basin, Mecsek Mts., Hungary.- Earth-Sci. Rev., 114/3-4, 250-278.

JONES, G. \& ROBERTSON, A.H.F. (1991): Tectono-stratigraphy and evolution of the Pindos ophiolite and associated units.- J. Geol. Soc. London, 148, 267-268.

JÓZSA, S. (1999): A darnó-hegyi óceánaljzati magmás kőzetek petrológiaigeokémiai vizsgálata. - PhD dissertation (Petrological and geochemical analysis of the submarine igneous rocks of the Darnó Hill), Eötvös Loránd University (in Hungarian with English abstract).

KARAMATA, S., KNEŽEVIĆ, V. \& CVETKOVIĆ, V. (2000): Petrology of the Triassic basaltoid rocks of Vareš (Central Bosnia).- Acta Geol. Hung., 43/1, $1-14$.

KISS, G., MOLNÁR, F. \& PALINKAŠ L.A. (2008): Volcanic facies and hydrothermal processes in Triassic pillow basalts from the Darnó Unit, NE Hungary.- Geol. Croat., 61/2-3, 385-394.

KISS, G., MOLNÁR, F., †KOVÁCS, S. \& PALINKAŠ, L.A. (2010): Field characteristics and petrography of the advanced rifting related Triassic submarine basaltic blocks in the Jurassic mélange of the Darnó Unit.- Centr. Eur. Geol., $53 / 2-3,181-204$.

KISS, G., MOLNÁR, F., KOLLER, F. \& PÉNTEK, A. (2011): Triassic rifting and Jurassic ophiolite-like magmatic rocks in the Bükk Unit, NE-Hungaryan overview.- Mitt. Österr. Mineral. Ges., 157, 43-69.

KISS, G., MOLNÁR, F., PALINKAS̆, L.A., KOVÁCS, S. \& HRVATOVIĆ, H. (2012): Correlation of Triassic advanced rifting related Neotethyan submarine basaltic volcanism of the Darnó Unit (NE Hungary) with some Dinaridic and Hellenidic occurrences on the basis of volcanological, fluid-rock interaction and geochemical characteristics.- Int. J. Earth. Sci., 101/6, $1503-1521$

KOHÚT, M. \& KISS, G. (2013): Plagiogranites from Szarvaskő (Bükk Unit, NE-Hungary): A monazite EMP dating. Occasional Papers of the Geological and Geophysical Institute of Hungary, 1, 28-29.

KOVÁCS, S., HAAS, J., SZEBÉNYI, G., GULÁCSI, Z., PELIKÁN, P., B.ÁRGYELÁN, G., JÓZSA, S., GÖRÖG, Á., OZSVÁRT, P., GECSE, ZS. \& SZABÓ, I. (2008): Permo-Mesozoic formations of the Recsk-Darnó Hill area: stratigraphy and structure of the pre-tertiary basement of the paleogene Recsk orefield.- In: FÖLDESSY, J. \& HARTAI, É. (ed): Recsk and Lahóca geology of the paleogene ore complex, geosciences. Publications of the University of Miskolc, Series A, Mining, 73, 33-56.

$\dagger$ †OVÁCS, S., HAAS, J., OZSVÁRT, P., PALINKAŠ, L.A., KISS, G., MOLNÁR, F., JÓZSA, S. \& KÖVÉR, SZ. (2010): Re-evaluation of the Mesozoic complexes of Darnó Hill (NE Hungary) and comparisons with Neotethyan accretionary complexes of the Dinarides and Hellenides - preliminary data.Centr. Eur. Geol., 53/2-3, 205-231.
KUBOVICS, I. (1984): On the petrogenesis of the North Hungarian basic-ultrabasic magmatic rocks.- Acta Geol. Hung., 27/1-2, 163-189.

KRANIDIOTIS, P. \& MACLEAN, W.H. (1987): Systematics of chlorite alteration at the Phelps Dodge massive sulphide deposit, Matagami, Quebec.Econ. Geol., 82, 1898-1911.

LEVINSON, A.A. (1974): Introduction to exploration geochemistry: Calgary, Applied Publishing, Ltd., $612 \mathrm{p}$.

MACLEAN, W.H. \& KRANIDIOTIS, P. (1987): Immobile elements as monitors of mass transfer in hydrothermal alteration: Phelps Dodge Massive Sulfide Deposit, Matagami, Quebec.- Econ. Geol., 82, 951-962. doi: 10.2113/gsecongeo.82.4.951

MESCHEDE, M. (1986): A method of discriminating between different types of mid-ocean ridge basalts and continental tholeiites with the $\mathrm{Nb}-\mathrm{Zr}-\mathrm{Y}$ diagram.- Chem. Geol., 56, 207-218.

MOLNÁR, ZS., KISS, G.B. \& ZACCARINI, F. (2015): Study of an epigenetic copper occurrence at the Darnó Hill (NE-Hungary) and its correlation with some Dinaridic and Hellenidic occurrences.- Carpathian J. Earth Environment. Sci., 10/2, 59-76.

MORIMOTO, N. (1989): Nomenclature of pyroxenes.- Can. Mineral., 27, 143156

MUKHERJI, S. (1972): Interaction of magma and sedimentary rock sin the Bükk Mountains, Hungary.- Acta Geol. Acad. Sci. Hung., 16, 29-42.

NADEN, J. (1996): CalcicBrine; a Microsoft Excel 5.0 add-in for calculating salinities from microthermometric data in the system $\mathrm{NaCl}-\mathrm{CaCl}_{2}-\mathrm{H}_{2} \mathrm{O}$.- In: BROWN, P.E. \& HAGEMANN, S.G. (eds.): PACROFI VI, Madison, WI.

NEHLIG, P. (1991): Salinity of oceanic hydrothermal fluids: a fluid inclusion study.- Earth Planet. Sci. Letters, 102, 310-325. doi: 10.1016/0012-821X(91)90026-E

NISBET, E.G. \& PEARCE, J.A. (1977): Clinopyroxene Composition in Marie Lavas from Different Tectonic Settings.- Contrib. Miner. Petrol., 63, 149160.

OZSVÁRT, P., DOSZTÁLY, L., MIGIROS, G., TSELEPIDIS, V. \& KOVÁCS, S. (2012): New radiolarian biostratigraphic age constraints on Middle Triassic basalts and radiolarites from the inner Hellenides (Northern Pindos and Othrys Mountains, Northern Greece).- Int. J. Earth Sci., 101/6, 1487-1501.

PALINKAŠ, A.L., BERMANEC, V., BOROJEVIĆ ŠOŠTARIĆ, S., KOLAR JURKOVŠEK, T., STRMIĆ PALINKAŠ, S., MOLNÁR, F. \& KNIEWALD, G. (2008): Volcanic facies analysis of a subaqueous basalt lava-flow complex at Hruškovec, NW Croatia-evidence of advanced rifting in the Tethyan domain - J. Volc. Geotherm. Res., 178, 644-656.

PAMIĆ, J. (1984): Triassic magmatism of the Dinarides in Yugoslavia-- Tectonophysics, 109/3-4, 273-277. doi: 10.1016/0040-1951(84)90145-8

PAMIC, J. \& TOMLJENOVIĆ, B. (1998): Basic geological data from the Croatian part of the Zagorje-Mid-Transdanubian Zone. Acta Geol. Hung., 41/4, 389-400.

PEARCE, J.A. \& CANN, J.R. (1973): Tectonic setting of basic volcanic rocks determined using trace element analyses.- Earth Planet. Sci. Letters., 19, 290-300.

PELIKÁN, P. (ed.) (2005): A Bükk-hegység földtana (Geology of the Bükk Mts.).- Magyar Állami Földtani Intézet kiadványa, Budapest, 284 p. (in Hungarian).

PÉNTEK, A, MOLNÁR, F. \& WATKINSON, D.H. (2006): Magmatic fluid segregation and overprinting hydrothermal processes in gabbro pegmatites of the Neotethyan ophiolitic Szarvaskő Complex (Bükk Mountains, NE Hungary).- Geol. Carpathica., 57/6, 433-446.

PETRELli, M., POLI, G., PERUGINI, D. \& PECCERILLO, A. (2005): Petrograph: A New Software to Visualize, Model and Present Geochemical Data in Igneous Petrology.- Geochem., Geophys., Geosyst., doi: 10.1029/2005GC000932

PICHLER, T., RIDLEY, W.I. \& NELSON, E. (1999): Low-temperature alteration of dredged volcanics from the Southern Chile Ridge: additional information about early stages of seafloor weathering.- Marine Geol., 159, $155-177$.

PIRAJNO, F. (2009): Submarine Hydrothermal Mineral Systems.- In: PIRAJNO, F. (ed.): Hydrothermal Processes and Mineral Systems, Springer, $1250 \mathrm{p}$.

POTTER, R.W. \& CLYNNE, M.A. (1978): Solubility of highly soluble salts in aqueous media - Part I. $\mathrm{NaCl}, \mathrm{KCl}, \mathrm{CaCl}_{2}, \mathrm{Na}_{2} \mathrm{SO}_{4}$ and $\mathrm{K}_{2} \mathrm{SO}_{4}$ solubilities to $100^{\circ}$ C. - J. Res. U. S. Geol. Survey., 6, 701-705.

RASSIOS, A. \& MOORES, E. (2006): Heterogeneous mantle complex, crustal processes and obduction kinematics in a unified Pindos-Vourinos ophiolitic slab (Northern Greece).- In: ROBERTSON, A.H.F. \& MOUNTRAKIS, D. (eds): Tectonic development of the Eastern Mediterranean Region. Geological Society, London, Special Publications, 260, 237-266. doi: 10.1144/GSL. SP.2006.260.01.11

ROBERTSON, A., KARAMATA, S. \& SARIC, K. (2009): Overview of ophiolites and related units in the Late Palaeozoic-Early Cenozoic magmatic and tectonic development of Tethys in the northern part of the Balkan region. Ophiolites and related geology of the Balkan region.- Lithos, 108/1, 1-36.

SADEK GHABRIAL, D., ÁRKAI, P. \& NAGY, G. (1996): Alpine polyphase metamorphism of the ophiolitic Szarvaskő Complex, Bükk Mountains, Hungary.- Acta Mineral. Petrol., 37, 99-128. 
SCHMID, M.S., BERNOULLI, D., FÜGENSCHUH, B., MATENCO, L., SCHEFER, S., SCHUSTER, R., TISCHLER, M. \& USTASZEWSKI, K. (2008): The Alpine-Carpathian-Dinaridic orogenic system: correlation and evolution of tectonic units.- Swiss J. Geosci., 101/1, 139-183. doi: 10.1007/ s00015-008-1247-3

SCHRAMM, B., DEVEY, C.W., GILLIS, K.M. \& LACKSCHEWITZ, K. (2005): Quantitative assessment of chemical and mineralogical changes due to progressive low-temperature alteration of East Pacific Rise basalts from 0 to 9 Ma. Chem. Geol., 218/3-4, 281-313.

SHIKAZONO, N., UTADA, M. \& SHIMIZU, M. (1995): Mineralogical and geochemical characteristics of hydrothermal alteration of basalt in the $\mathrm{Ku}-$ roko mine area, Japan: implications for the evolution of a back arc basin hydrothermal system.- Appl. Geochem., 10, 621-642. doi: 10.1016/08832927(95)00032-1

SKILLING, I.P., WHITE, J.D.L. \& MCPHIE, J. (2002): Peperite: a review of magma-sediment mingling.- J. Volc. Geotherm. Res., 117, 1-17. doi: 10.1016/S0377-0273(01)00278-5

SUN, S.S. (1980): Lead isotopic study of young volcanic rocks from mid-ocean ridges, ocean islands and island arcs. Philos.- Transact. Royal Soc., A297, 409-445. doi: 10.1098/rsta.1980.0224

SUN, S.S. \& MCDONOUGH W.F. (1989): Chemical and isotopic systematics of oceanic basalts: implications for mantle compositions and processes.- In
NORRY, M.J. \& SAUNDERS, A.D. (eds.): Magmatism in the ocean basins.- Geological Society, London, 313-345. doi: 10.1144/GSL. SP.1989.042.01.19

SZENTPÉTERY, ZS. (1953): A Déli-Bükk-hegység diabáz és gabbrótömegei (The diabase and gabbro bodies of the Southern Bükk Mts.).- Magyar Állami Földtani Intézet Évkönyve, 41/1, 1-102 (in Hungarian).

TRUBELJA, F., BURGATH, K-P. \& MARCHIG, V. (2004): Triassic Magmatism in the Area of the Central Dinarides (Bosnia and Herzegovina): Geochemical Resolving of Tectonic Setting.- Geol. Croat., 57/2, 159-170.

ULRICH, T. \& HEINRICH, C.A. (2002): Geology and Alteration Geochemistry of the Porphyry $\mathrm{Cu}-\mathrm{Au}$ Deposit at Bajo de la Alumbrera, Argentina.- Econ. Geol., 97, 1865-1888. doi: 10.2113/gsecongeo.97.8.1865

WILSON, M. (1989): Igneous Petrogenesis. A global tectonic approach.- Harper Collins Academic, London, 466 p. doi: 10.1007/978-94-010-9388-0

ZANE, A. \& WEISS, Z. (1998): A procedure for classifying rock-forming chlorites based on microprobe data.- Rend. Linc. Sci. Fis. Nat., serie 9, 9, 51-56.

ZANG, W. \& FYFE, W.S. (1995): Chloritization of the hydrothermally altered bedrock at the Igarapé Bahia gold deposit, Carajás, Brazil.- Mineral. Dep., 30, 30-38.

ZHANG, Y.G. \& FRANTZ, J.D. (1987): Determination of homogenization temperatures and densities of supercritical fluids in the system NaCl-KCl- $\mathrm{CaCl}_{2}-$ $\mathrm{H}_{2} \mathrm{O}$ using synthetic fluid inclusions.- Chem. Geol., 64, 335-350. 